\title{
A History of Network and Channels Thinking in Marketing in the $\mathbf{2 0}^{\text {th }}$ Century ${ }^{*}$
}

\section{Ian Wilkinson}

School of Marketing, University of New South Wales, Sydney, Australia

(Australasian Journal of Marketing 9 (2) 2001, 23-53)

\begin{abstract}
The development of research explaining the structure and operations of interfirm relations and networks in marketing channels and business markets is described. The focus is on the main contributors and research themes that have underpinned the development of marketing thought in this area since the beginning of the $20^{\text {th }}$ century. I show how ideas have been borrowed from other disciplines such as economics and the behavioral sciences to inform research and develop marketing theory and how different but overlapping research traditions emerged in North American, Europe and Australasia. A broad picture is painted of the intellectual history regarding the subject of interfirm networks, rather than a detailed exposition of particular theories or contributions. This is followed by a state of knowledge assessment in terms of five fundamental explananda identified at the outset of the article. I conclude by discussing some of the main research issues challenging researchers in the next millennium.
\end{abstract}

Keywords: History of thought, Marketing Channels, Distribution, Business Networks, Inter-firm Relations, Marketing Theory 


\section{BIOGRAPHY}

Ian Wilkinson is Professor of Marketing at the University of New South Wales. Prior to returning to UNSW in 2001 he was the Foundation Professor of Marketing at the University of Western Sydney. He was educated in the UK and Australia and was awarded the first PhD in Marketing at UNSW in 1973. He has held academic posts at various American, European as well as Australian universities including: University of Bath, University of California at Berkeley, University of Cincinnati, Lancaster University, Stockholm School of Economics, Temple University and the University of International Business and Economics, Beijing. He has published three books and over 100 research papers and he is a member of the editorial review board of a number of international journals. The focus of his research and teaching is in the areas of interfirm relations and networks, international marketing, marketing theory and marketing dynamics. 


\section{MANAGEMENT AND POLICY IMPLICATIONS}

Competition today is increasingly being portrayed as competition among business networks rather than individual firms. Firms specialise in performing some activities and depend on others for other activities, including suppliers, distributors, service providers, customers, and those providing complementary products. For management the key issues are what activities it is going to do itself and what it is going to rely on others to do i.e the make or buy decision, and how it is going to develop and manage its relations with other firms on whom it depends for various products and services. For governments the issue is how to assist in the development of internationally competitive business networks that will contribute to the economic development of the nation and that will provide people with desired goods and services in an effective and efficient manner.

These issues are not new and, in one form or another, have been the subject of much research and theory development over the years in marketing and allied disciplines. This article reviews the development of thinking related to these issues since the beginning of the $20^{\text {th }}$ Century, focusing attention on five fundamental questions or explananda. It identifies the main economic principles that affect the specialization of firms in different activities and the emergence of marketing intermediaries. It also shows how various constraints, especially the problem of managing relations between firms, affect the structure of business networks and marketing channels that develop over time. This understanding provides a basis for management and policy makers' decisions regarding participation in and regulation of business networks and will assist them in analyzing the advantages and disadvantages of various network and relationship strategies that are currently in vogue, such as outsourcing, relationship marketing, partnering, supply chain management, network organization. It also reveals the limits of our understanding and the problems and issues we must address in the future. 


\section{"The further backward you can look, the farther forward you are likely to see"}

\section{Winston Churchill}

\section{Introduction}

The study of interfirm relations and networks can be traced to early civilizations, as people tried to understand the emergence of various institutional arrangements associated with the buying and selling of products and services, including the emergence of markets, retail and wholesale institutions, international trading systems and the like (e.g. Dixon 1982, 1984, 1991). The purpose of this article is to put into perspective the study of one aspect of marketing by tracing its historical development in the twentieth century. The timing is appropriate: as we commence the $21^{\text {st }}$ century we can reflect back on the $20^{\text {th }}$ and see what we have learned.

I take a broad view of the field of interfirm relations and networks. It is meant to include theories or concepts developed to help explain why systems of interrelated firms and other organizations arise to carry out production and marketing work. In the marketing discipline this includes the study of: marketing and distribution channels in domestic and international markets; supply chains; business to business markets and the nature and role of relations between buyers and sellers; and institutional studies of intermediaries such as retailers and wholesalers. Each of these areas draws heavily on research from other disciplines including economics, geography, sociology, politics, psychology, social psychology and law.

\section{Why Study History?}

There are many reasons for studying history. As the Churchill quote at the beginning of this article suggests, history can teach us about the future. In terms of our understanding of business networks this means that insights into current problems and issues can be found by examining earlier work. In his article for the $60^{\text {th }}$ 
anniversary issue of the Journal of Marketing George Day summarised the role of the study of history this way:

"Histories serve many functions. They reveal our origins, celebrate our successes, and remind us of our debts to our intellectual ancestors. A history also helps interpret the past by identifying the reasons for important transitions." (p 14)

The history of thought to be described reveals the way our ideas have developed over the last century and reveals something of the sociology of science and knowledge development. It shows how earlier scholars sometimes addressed issues that could only later be taken up and developed, as methodologies improved and complementary areas of theorizing emerged permitting a fuller realization of the earlier ideas. We see how the practice of science is influenced by the timing of the introduction of ideas, the nature of the environment of ideas and theories into which a new theory or insight is borne. History matters in the sense that theory development is path dependent: the emergence of particular scholars and ideas at particular times and places shape future research and theory development. We will see the way economic ideas dominated early theory development and how this gave way to the introduction of theories from other social sciences as they developed - beginning in particular with the work of Wroe Alderson and his colleagues. Later, the empirical revolution shaped the way research on the behavioral dimensions of interfirm relations developed. Lastly, we see how the way a question is initially framed and the initial focus of interest can entrain a particular path of development - as in the focus on power and conflict in the study of behavioral dimensions of interfirm relations.

A final reason for studying the history of thought is that many scholars today do not have the time or inclination to delve into history to discover and read the original formulation of concepts and theories. This 
can lead to an unfortunately narrow and biased view of the nature and sources of ideas. It can lead to misunderstandings and misinterpretations of the original concepts and even to mistakes that could have been avoided had earlier contributions been better understood. One example of this is work on the economic principles underlying the existence of channel intermediaries and the nature and role of diseconomies of scale that led to a misrepresentation of earlier economic principles (see section on economic principles and network structure).

\section{Scope and Organisation}

This article goes some way to providing a broader historical backdrop to the study of channels and business networks. Having said this, it should be noted that there is a vast and growing literature in this area and it is impossible in one article to do justice to all the various contributions. But this is not my purpose. The purpose here is to describe the broader intellectual pathways that have led us to where we are today, or what may be described as "Big History" (Christian 1991). It is not meant to be a complete history of the development of marketing thought like the work of Robert Bartels (1962) but one focused on a particular aspect of marketing theory. The history described necessarily reflects a personal view of the important events, concepts and people that have shaped our thinking, based on my own research and teaching in the area in Australia, Europe and the USA. It is thus a Western view of intellectual development in the area based on publications in English. Some of the people and concepts are well known and accepted, others less well known, even though their ideas, I contend, underpin more familiar theories and approaches. I am sure some will feel that important sub-themes and people are left out or not given sufficient prominence in the history described and that others (such as my own efforts!) are over-represented. This is perhaps inevitable in a subject as broad as this covering such a long period. 
The article is organized as follows. First, the fundamental research questions concerning business networks are discussed. The history of thinking and research in the area is then described in terms of various evolving and interconnected streams of research, beginning with the work of early economic and social theorists in the first half of the twentieth century. From then on the history is organized, for convenience, primarily by decade but it is linked also to key contributions and transition points in thinking and research.

In terms of number of publications most research in the area has taken place in America but in this review I include sections on European and Australasian contributions. This is done for the following reasons. First, important contributions and different approaches have emerged elsewhere which have not been fully represented in American publications. Second, by considering the work going on in other parts of the world we gain a better appreciation of how ideas develop in part in response to local contexts and opportunities. Of course, the focus on Australasian and European contributions also reflects my own interest and involvement in this area of research. Finally, because this article is being published in the Australasian Marketing Journal, it is appropriate to summarise the development of research in this part of the world.

After describing the patterns of development of ideas I return to the fundamental research questions and consider how far we have progressed. This leads on to a final section in which some potential areas for future research are discussed.

\section{The Explananda}

Marketing channels or business networks refer to the interdependent systems of organisations and relations that are involved in carrying out all the production and marketing activities involved in creating and delivering 
value in the form of products and services to intermediate and final customers - what is now coming to be referred to a value chains, systems or networks. There are at least five fundamental research questions concerning the structure and operation of such networks:

- Why are networks structured the way they are? This includes the reasons for particular types of organizations existing at different times and places, the reasons for activities being divided up among them and the nature of the relations or connections among the organizations and activities.

- To what extent and how are the activities of different organizations in a network coordinated, managed and controlled?

- How and why does the structure and coordination of a network change over time, i.e. how does it develop and evolve?

- How do we identify and create optimal or better performing networks?

- How do (and should) individual organizations in a network deal with their relations with others in the network?

\section{The Founding Fathers and Mothers: 1900 - 1950s}

The beginning of systematic theories of the structure and coordination of business networks in the $20^{\text {th }}$ Century may be traced to the early institutional economists who contributed some of the basic concepts and principles that have become the foundation for later research. I have selected three that I believe have been particularly influential i.e. John Commons, Joseph Schumpeter and Ronald Coase ${ }^{1}$.

John Commons, combined ideas from law, economics and psychology in his 1934 book Institutional Economics, which was further developed in The Economics of Collective Action published in 1950 after 
his death. Commons focused attention on transactions as the basic unit of analysis and on the processes involved. He identified three different types of transactions: a) bargaining transactions, involving the transfer of property rights; b) managerial transactions between superior and subordinates; and c) rationing transactions, involving primarily government distribution of burdens (e.g. taxes) and benefits (e.g. budgets) among people. He showed how collective economic organization, i.e. economic institutions, arises and evolves to manage the inherent conflicts of interests among individuals and how collective organization is in control of individual action in that it both constrains and enables it. This basic idea is to find its expression again in the 1980s and 1990s in discussions of network strategy and the concept of network position. He also distinguished between strategic transactions that alter the nature of agreements and shape subsequent routine transactions.

His work made important contributions to the conceptualization of market exchange and to the role of behavioral and economic dimensions. His process oriented and dynamic theory of collective organization influenced Wroe Alderson's conceptualization of market transactions and organized behavior systems (see below) as well as more recent attempts to model the dynamics of organization and network structures. ${ }^{2}$ Joseph Schumpeter $(1939,1947)$ also focused on processes underlying industrial organization and its evolution. He showed how the struggle for survival among different types of organizations and networks, competing to serve the needs of society, shape the evolution of industrial structure. According to Schumpeter, institutional change stems from a process of innovative competition, rather than the more limited concept of price competition. Organizations and business networks adapt to changing conditions and new technologies in their attempts to carve out a place for themselves in the business system. His ideas provide the basis for many concepts commonly used in marketing such as differential advantage, innovative 
competition and value delivery systems and influenced more recent attempts to develop computer-based models of industrial organization (e.g. Nelson and Winter 1982, Arthur et al 1997).

The third major figure of this time is Ronald Coase (1937), who introduced the concept of transaction costs, which eventually led to the award of a Nobel Prize in Economics. His work represents a further development in the conceptualization of exchange and in particular the costs of reaching agreements as well as coordinating, controlling and implementing them. Coase addressed the issue of why firms exist instead of a system of market transactions linking individual economic actors. Being an economist he begins with the premise that "first there were markets" and then seeks to understand why firms exist. In marketing we tend to put the problem around the other way. We start with a firm and seek to explain why it delegates or outsources various activities rather than doing them itself. It is the same problem. Coase's work has been developed significantly in more recent times by Oliver Williamson in ways that have had a profound influence on marketing theories of business networks as well as economic theory generally as will be discussed in a later section.

\section{Economic Principles and Network Structure}

In addition to these more general concepts regarding the structure and coordination of business networks, various economic principles were being developed in the first half of the $20^{\text {th }}$ century that contributed to our understanding of intermediaries and network structure. The main ones are listed in Table 1.

\section{Insert Table 1 about here}

Marshall in his Principles of Economics (1889) and Industry and Trade (1919) considered some of the efficiencies that arise from large-scale production, and how the efficiencies of intermediaries, such as wholesalers and retailers, arise because they perform marketing activities on a larger scale. Also, the 
problem of finding more efficient ways of marketing at a distance was seen as a major concern, an issue that was to become an important focus of attention in marketing in the study of distribution systems.

Shove (1930) extended the analysis of distance and costs and showed how geographic distance and the associated increases in transport costs per unit sold limited the market reach of a firm. The result was that firms were constrained as to the efficiencies they could gain in production and other tasks. This concept was later extended to include psychological distance resulting in increased communication costs per unit sold as more "distant" customers need to be identified and attracted (e.g. Alderson 1957, Hallen and Wiedersheim-Paul 1979).

Robinson (1931) provided a more systematic account of the role of economies of specialization and scale effects in shaping the pattern of specialization among firms. He showed how external economies arise from relying on other firms to perform certain activities because of the scale efficiencies they can gain that are not available to the firms using their services.

Sergeant Florence (1933) further developed the principles underlying scale economies, noting that many different types of scales exist, including plant, establishment, enterprise, and transaction. Different scales and sources of efficiencies are associated with the performance of different kinds of activity. He identified three important principles: the principle of multiples, bulk transactions and massed reserves. The principle of multiples refers to the lumpiness of factor inputs, such as machines, land and workers, that operate most efficiently at different scales that do not necessarily coincide. As a firm expands it is better able to match the scales of different operations and minimize slack or over use through the principle of the highest common factor. The principle of bulk transactions concerns the efficiencies arising from larger scale transactions, such as larger scale purchases, shipments, communication, and negotiations, through the use of 
specialized inputs, fuller use of fixed inputs and set up costs, including transport links, rail cars, trucks, drivers, sales personnel and credit arrangements. Efficiencies here also result from engineering and design principles, which mean that some dimensions of activities and resource inputs increase at a faster rate than others e.g. area versus volume. The principle of massed reserves shows how inventory costs as a percent of total costs decrease with increased sales because fluctuations in demand are more likely to cancel each other out as there are more customers. This principle is the same in essence as that of pooled uncertainty proposed by Stigler (1946) and concerns the gains from spreading or pooling of uncertain events over a larger set. It is the principle that underlies insurance and sampling theory.

Lady Margaret Hall (1949), in her study of distribution, introduced the principle of minimized total transactions, that is directly linked to the existence of marketing intermediaries. She showed how the introduction of retailers and wholesalers reduces the total number of transactions required to link a number of sellers to a number of buyers. This principle has been generalized to all types of marketing activities including communication, transport, payment and contract negotiations and results in the familiar diagrams used in marketing textbooks to demonstrate the efficiency of intermediaries.

The economies of specialization are only potential economies, as Florence noted. This means that activities have to be undertaken at appropriate scales but other required activities and the size of the firm limit the firm's ability simultaneously achieve all types of efficiencies. These constraints were clarified by Stigler (1951) in his well known paper: "The division of labor is limited by the size of the market." In this he examines the average cost curves for different types of activities of a firm and showed how increasing cost activities constrain the ability of a firm to achieve savings in other activities. Stigler did not provide many examples of increasing cost activities, as his focus was more on production activities. But marketing (as 
well as management) activities are examples of increasing cost activities, as Shove had already pointed out, and they include increasing transport and communication costs necessary to reach more physically and psychological distant customers. Increasing costs per unit sold occurs even though the costs per unit transported or communicated are falling. This distinction between the scale of an activity and that of the firm has caused some confusion in marketing as increasing costs activities have been presented as inefficiencies leading to diseconomies of scale. These "inefficiencies," it is sometimes argued, cause firms to spin-off such functions to smaller more efficient specialists (e.g. Mallen 1973). The correct interpretation is that, as firms undertake more transport and communication activities they become more efficient due to the various types of scale economies described. But the increasing distance to markets leads to average costs per unit sold eventually rising. If it was just a matter of remaining "small" to be efficient in performing these activities a firm could duplicate a number of small departments or establishments itself. But the "smaller" specialist is actually operating at a larger scale, or rather scope, for particular activities by combining the work of several firms - just like any specialist $\mathrm{t}^{3}$

The focus on different types of activities and variations in the efficient scales of operation for them led Boulding (1953) to propose a general theory of growth that he termed the principle of non proportional change. The different parts of a system do not grow at the same rate as the growth of the overall system, resulting in tensions among the efficient operation of different parts. A similar principle is reflected in Penrose's (1959) theory of the growth of the firm, which has become an important foundation for the theory of economic organization. The conflict among efficient scales of operation for different activities can be handled in part by the outsourcing activities to specialists that perform similar activities on behalf of a number of firms and gain efficiencies through the aforementioned economic principles. As a result of this 
division of labor between firms external economies are gained and an economic explanation for network structure is provided in terms of cost efficiencies.

\section{Early Marketing Theorists}

So far the contributions described have been from economists, but there were important contributions made by marketing scholars in the first half of the $20^{\text {th }}$ century in describing and explaining the structure of channel networks. Some of the main contributors are listed in Table 2.

\section{Insert Table 2 about here}

Early descriptions of marketing institutions and their functions - the so-called institutional and functional approaches to marketing were largely a-theoretical enumerations and classifications. But there were some notable exceptions.

An early pioneer was Macklin who in 1921 published a book on Efficient Marketing for Agriculture that includes discussions of the rationale underlying the structure of marketing systems in terms of interrelated systems of local organizations federated into one or more central organizations. ${ }^{4} \mathrm{He}$ stressed the importance of the working relations between farmers and local middlemen and between different levels of middlemen in bringing about successful and efficient marketing. His work can be seen as the forerunner of work on marketing and economic development and the way the development of marketing institutions linked local markets into larger scale markets that permitted the process of economic specialization and innovation to be supported. This is accomplished by providing outlets for the resulting products and services as well as incentives to develop and innovate because of the different types of products and services made available through these linked markets (e.g. Moyer and Hollander 1968, Slater 1968). Macklin also discussed marketing activities in terms of assembling, grading, standardizing and distributing, 
which are forerunners of the collecting, sorting and dispersing concepts developed later by Vaile, Grether and Cox and Alderson, as discussed below.

Another early pioneer was Ralph Breyer (1924) who, in an early text The Marketing Institution incorporated ideas from psychology and social psychology and tried to develop a holistic view of marketing. He introduced the idea of marketing flows, portraying marketing structures in terms of the flow of electric current through networks of wires when connections are made. A long serving faculty member at the Wharton School at the University of Pennsylvania, his main contribution was in terms of providing a systems oriented approach to depicting, conceptualizing and quantifying channels in order to aid channel control and improve efficiency. He distinguished business unit channels, enterprise channels, business type channels and channel groups in terms of the level of aggregation of the business actor involved, which helped clarify analysis. He also attempted to develop a more systematic analysis of channel costs (Breyer 1949).

Reilly (1931) examined some of the factors governing the spatial structure of channel networks in his theory of retail gravitation. He drew on central place theory from economic geography and showed how intermediate-trading communities developed between larger towns according to empirical attraction rules. This was the forerunner of later work on market areas and spatial patterns of trade and marketing. A major study of distribution was conducted by Stewart, Dewhurst and Field (1939) entitled Does Distribution Cost Too Much? They attempted a systematic evaluation of the costs of distribution in the US, "under great difficulties at a time when statistics were scarce and when intellectual concepts concerning distribution were confused and uncertain" (Cox et al 1965, p 7). Their study was not equaled until 1965 when Cox and his colleagues produced their study (see below). 
In the late 40s and 50s there was increasing dissatisfaction with the state of theorizing in marketing, which was first articulated by Alderson and Cox in their 1948 article in the Journal of Marketing. They proposed various ways in which marketing theory could be advanced, including making use of ideas from institutional economics, geography and other behavioral sciences. This set the scene for many of the developments that took place in the next decade or so centered to a large extent on the work of Wroe Alderson and his colleagues at Wharton ${ }^{5}$. The contributions of Alderson are considered in the next section. For the remainder of this section I review important contributions by marketing scholars emerging in the 1950s.

McGarry (1951) offered a classification of generic marketing functions, which went beyond the more descriptive accounts. In particular, he proposed a contactual function, by which firms develop and maintain webs of relations with other firms that lead to system flexibility and adaptability. He also noted that the initiative in organizing interfirm networks could come from various locations, including both producer and consumer ends of the channel. This was one of the first attempts to depict channel structure as complex adaptive networks co-produced by the organizations involved and not necessarily dictated by one organization or channel captain. McVey (1960) further emphasized the point that channel networks were not necessarily under the control of one type of organization and that organizations often face very limited choices in "designing" the channels for their products or services. Their work, along with Alderson's contributions discussed in the next section, herald the beginning of a greater focus of attention on issues of channel management and control - issues that were to become an increasing focus of attention towards the end of the 1960s. 
A neglected but important classic was a book published in 1952 by Vaile, Grether and Cox entitled Marketing in the American Economy. This combined the thinking of many scholars to develop a framework for analyzing the marketing system of a society, including the complex structure of linked institutions making up production and distribution systems. The book begins with a chapter on the "complexities of breakfast," that shows the complex systems of organizations and transactions involved in bringing together the assortment of goods and services required to enjoy breakfast in an American household of the time. The work of marketing was characterized in terms of collecting, sorting and dispersing and marketing flows, and some of the principles governing the emergence of intermediaries and other forms of marketing organization were described. The spatial structure of channel networks as well as the division of work among different types of organizations was considered.

An alternative conceptualization of the marketing system was proposed by Duddy and Revzan (1953). Their holistic-institutional approach is an early attempt to incorporate system theory notions into the analysis of marketing structures. Unfortunately, their work tends to be overlooked by later scholars because the term institution became associated with the more narrow and sterile approach of describing types of marketing organizations and their functions - the Institutional School. Also, their theoretical contribution was buried in an appendix to an otherwise more traditional marketing textbook of its time, which did not help its promotion. Systems theory ideas and functionalism in the deeper sociological sense were to find expression in the work of Wroe Alderson and later scholars.

The first comprehensive in-depth study of a business network was undertaken in the 1950s (Cox and Goodman, 1956). Its aim was to map out and analyse the patterns of transactions and organizations involved in supplying the goods and services needed for building a house in Philadelphia. A massive amount 
of data was collected tracing the origins of the materials back through multiple transactions and organizations to the original sources of supply, such as to the timber in a forest or to the minerals in a mine. Only a small taste of the output was provided in the article. The type of data gathered would be capable now of a much more thorough and sophisticated analysis, given the advances that have been made since in the computer analysis of network data. It is unlikely that such a study will ever be carried out again and it is a pity that the data gathered appears to be no longer in existence.

In the same year that the Philadelphia housebuilding study was published, Leo Aspinwall (1956) proposed a systematic means of classifying goods in terms of factors affecting the most appropriate and economical means of promoting and distributing them. He identified five important attributes i.e. replacement rate, gross margin, adjustment (services to tailoring a product to the specific needs of customers), time of consumption (durability) and searching time. These were combined into a general scale he described in terms of a color scale. The mix of direct and broadcast distribution appropriate depended on the placement of products on this color scale. The attributes affect the demand for various types of marketing activities and, therefore, the potential efficiencies to be gained from specialization. The characteristics of goods could change over time as they became better known and developed and thus distribution and promotion systems change. Aspinwall's approach was the forerunner of more sophisticate analytical models to be developed later.

Finally, contributions were made to the economic analysis of channel structure. Balderston (1958) presented a model showing the interaction between the economies of specialization and the process of competition. He showed how an intermediary setting up between a set of sellers and buyers reduces system costs by reducing the number of number of transactions but it is a monopolist that can charge high prices and earn supernormal profits, which attracts in more intermediaries who introduce competition and 
bring about price reductions. But additional intermediaries divide the market in some way that limits the economies of reduced transaction and drives up the overall costs in the system. There is a limit to the number of intermediaries that can be supported, depending on the nature of price competition and the costs of entry. By making various simplifying assumptions, formulae for the maximum number of intermediaries can be determined. He developed his model further in the form of a computer simulation of the marketing channel for the lumber industry (Baldertson and Hoggatt 1962).

\section{Wroe Alderson}

Wroe Alderson's work is singled out for more extensive review because it represents a watershed in the development of marketing thinking and in particular about the structure and operations of channel networks and marketing institutions. His ideas were developed and refined over the years through the work he did for his consulting company, Alderson and Sessions, as well as through his research and teaching at the Wharton Business School. Many of his ideas were first proposed in his consulting firm's journal Cost and Profit Outlook. Alderson's perspective is that of a participant in the marketing process (usually the seller), rather than an outside observer. He saw the role of theory as helping to improve practice. This contrasts with earlier writing, such as Vaile Grether and Cox (1952), which is more descriptive in character and adopts more the perspective of an outside observer.

Some of Alderson's major conceptual contributions are listed in Table 3. Alderson is a functionalist, not in the narrow sense of describing types of marketing functions, but in a deeper sociological sense, as an intellectual framework for integrating our understanding of the marketing system as a socio-economic system. He sought to understand the nature of work and the functional prerequisites of a marketing system 
and the way in which marketing organizations arise to carry out this work. This understanding, he argues, is the basis for making such systems work better.

\section{Insert Table 3 about here}

Alderson distinguishes between the function and structure of a system, Function refers to the work, behaviour or activities to be performed by the marketing system and structure refers to the types of organizations and linkages among them that arise to do this work. In terms of functions, the primary unit of analysis is the transaction, drawing on the work of John Commons ${ }^{6}$, and the work of marketing is accomplished through systems of transactions (transvections) linked in series and parallel. The work involved in bringing about transactions and transvections is conceptualised in terms of various kinds sorting processes, i.e. allocating, accumulating, sorting out and assorting, to overcome the discrepancies of assortments between sellers and buyers. The discrepancies of assortments include those of time, place, form, ownership and value, that separate producers and consumers ${ }^{7}$ and, in a macro sense, separate the conglomerations of resources found in nature from the meaningful assortments of goods and services demanded by a society.

Transactions and transformations alternate in marketing systems as decisions and negotiations among buyers and sellers about the sorting of goods gives way to actual transformations in time, space and form. While these concepts of work can be applied to all kinds of marketing activities, Alderson's focus is primarily on physical distribution activities and the distinction between marketing and production activities becomes fuzzy.

Efficiencies are sought in carrying out marketing activities and this drives the structure of the marketing system. These efficiencies are to be found in the performance of transformation activities as a result of 
specialization, scale economies and reduced contacts but also in the negotiation of transactions. The latter is reflected in his distinction between fully negotiated and routine transactions, which links to the concept of transaction costs. Efficiencies are also to be found in terms of the optimal number of sorts and transformations i.e. in the number of levels and types of intermediaries in the distribution network, which determine the "shortest," i.e. least costly, route to market.

Alderson (1950) introduced the principle of postponement as a way of seeking efficiencies in the carrying out of marketing tasks. Postponement means locating more of the sorting and matching processes closer (in time and distance) to the final customer, where the character of demand may be better understood and more closely matched. The opposite of postponement is speculation, which involves undertaking sorting activities at earlier stages in the network in order to get the advantages of centralized, large-scale operations.

The work of marketing is carried out within and between various types of organisations that are termed organized behavior systems (OBS). The main types of OBS are the primary systems of firms and households, as well as channel systems, which he regarded as more loosely coupled. OBS involve both economic and behavioural dimension and have operating, control and communication subsystems by which work is planned and carried out and members of the system are rewarded. Various economic and behavioral principles are used to understand the way OBS come into existence and specialize in particular assortments of activities within the overall marketing process. Cooperative as well as competitive processes are highlighted as people and firms seek to cooperate to gain rewards they otherwise could not but, at the same time, seek their independence from the will of others and evaluate opportunities in terms of 
their selfish needs. This tension between independent and collective action is reflected in his notions of monostasy (standing alone) and systasy (standing together).

The dynamic nature of marketing structures and the problems confronting participants in marketing systems is emphasized through concepts such as the search for differential advantage, the proliferation of opportunity, and his power principle that says that firms should act so as to maximize their ability to act. Firms seek out competitive niches in the overall system that allows them to specialize in particular assortments of activities that match the requirements of others better than alternatives and which sustain the organization. In this way the structure and operations of the business networks comprising the marketing system are continually made and remade.

\section{0s: The Economic Structure of Distribution Channels}

From Alderson's time a number of contributions start to emerge in America concerning the nature of the economic structure of channels and business networks and the problems confronting the managers of firms. Many of the most important contributions discussed below were brought together in Mallen's (1967) edited collection of readings The Marketing Channel.

Studies of distribution systems around this time took a more macro view of the structure of distribution, the most notable being Cox, Goodman and Fischandler (1965) Distribution in a High Level Economy. This built on the pioneering study by Stewart et al (1939) and used US census data to show the complex patterns of trade flows in the economy and brought together various economic principles to help explain it. The book used the concept of marketing flows, including flows of products and services, information, risk 
and title to describe the marketing activities taking place through distribution networks. The analysis of the structure of trade flows was taken up later in the 70s and 80s by Layton (1981a, 1981b, 1984).

Bert McCammon (1963) contributed to our understanding of network change and evolution, drawing on the earlier work of Schumpeter and Coase. He brought together research and concepts from various behavioral sciences to examine the processes of change taking place in channel systems. In addition, in a major synthesis of the literature, McCammon and Little 1965, used a systems theory framework to bring together economic theories of channel structure with research on the political and social dimensions of channel behavior, including an extensive bibliography of research up to that time. They highlighted the problems as well as the opportunities of channel coordination and management and the lack of welldeveloped theories in these areas.

Baligh and Richartz (1967), in their book Vertical Market Structures, further extended Balderston's (1958) economic analysis of channel structure to include more kinds of marketing activities. They also added the opportunity for additional types of intermediaries to enter the network between the first level intermediaries and the original buyers and sellers. The economies of specialization from reduced transactions and scale economies together with the price competition resulting from the entry of competing intermediaries results in the development of multiple levels of intermediaries, resembling the patterns observed in actual distribution networks. Much later Zusman and Etgar (1981) showed how the interaction between specialization and competition can result in cyclical patterns of change in structure as changes in the number of intermediaries at one level in the network alter the economies of specialization at other levels and hence the number of intermediaries that can be supported. 
Bucklin $(1960,1965,1966)$ provided a major step forward in the economic analysis of business networks. He focused on the main types of functions carried out in a channel of distribution and considered the costs of performing these functions with different patterns of specialization among organizations in the channel. The overall costs depended on scale economies and interaction effects among activities, including tradeoffs for example between inventory and transport modes, as well as on the additional activities that must be carried out when specialist intermediaries are introduced. For example, extra levels of transactions, intermediate stocks and transportation arise to link different levels in the channel network. He distinguishes between the normative channel in which costs are minimized and the extant channel, which is the one in operation. Because of the problems of taking into account all the cost functions and interactions, and because these change as a result of technological and market changes, there is always likely to be a gap between the extant and normative channel structure. His model brought together in a clear manner many of the factors shaping the structure of channels. He also developed the notions of postponement and speculation, first advanced by Alderson, showing how the tradeoffs involved can be represented in simple cost curves (Bucklin 1965). His general approach to analyzing channel structure strongly influenced the analysis of physical distribution systems, where costs and activities are easier to identify, but the application to non physical flows remained underdeveloped until the 1980s when a number of analytical models were proposed, as discussed in a later section.

In Bucklin (1972) he further developed his ideas and explored issues related to the productivity of distribution systems that few in marketing have taken up (for an exception see Ingene, 1985). However, in addition to his work in marketing, important studies of productivity in distribution were undertaken by applied economists in the USA and UK (e.g. Hall et al 1962, George 1966, Ward 1973). 
Another development in the 1960s were computer models of channel systems developed to study the dynamics of the interaction among activities and how this affected performance. Forrester's (1961) models of industrial dynamics and Balderston and Hoggat (1962) models of market processes were the forerunner of later logistics models developed by Bowersox (1972) and his colleagues and eventually to the evolutionary models of network structure emerging in the 1990s (Wilkinson 1990, Easton et al 1997).

\section{Institutional Studies}

A stream of research focused on the characteristics and evolution of distribution systems and institutions. Some early theories of the patterns of change taking place were advanced in terms of the Wheel of Retailing and Accordion Theory (Hollander 1960, 1966) and attempts were made to understand how environmental factors shaped the pattern of development of distribution networks and how distribution changed as economic development took place (e.g. Moyer and Hollander 1968,Wadinambiaratchi 1965). Descriptive and comparative studies of distribution systems and institutions in different cultures were undertaken (e.g. Bartels 1963, Boddewyn and Hollander 1972, Cundiff 1965, and Revzan 1961). Some general frameworks were proposed for organizing the various types of factors shaping the nature and evolution of channel institutions and marketing systems and this led to the development of a number of comparative marketing systems studies. But the contributions were largely descriptive without any substantive theory building or testing.

A more theoretically based approach is to be found in a series of studies and models of the structure and operations of marketing and distribution systems in La Plaz, Bolivia, developed by researchers at Michigan State University (e.g. Slater 1968). These were undertaken with the aim of understanding how changes in 
distribution systems could contribute to economic development. The ideas were taken up later by Layton (1985) to analyze the role of distribution linkages in regional economic development in Indonesia.

Before leaving the 1960s it is worth mentioning the publication of a small volume by Lewis (1968), which attempted to integrate the literature on marketing channels in terms the functions, evolution, management and theory of channels.

\section{The 1970s: The Behavioral Dimensions of Channels:}

As noted already, the issue of channel control began to gain increasing interest towards the end of the 1960s. This was partly a result of Alderson's writings and to researchers starting to draw more on ideas from other behavioral disciplines but also stemmed from the changing realities of distribution, such as the struggle for channel control between manufacturers and large scale retailers (e.g. Craig and Gabler 1940), the conflicts occurring at the time in franchised distribution systems such as the automobile industry (e.g. McCammon and Little 1965) and what Chandler referred to as the emergence of the visible hand controlling the operation of vertical marketing systems (Chandler, 1977)

McGarry's (1951) work on the contactual function highlighted the role of relations and contacts among organizations. McCammon (1963) and McCammon and Little (1965) drew upon behavioral theories and research to show how the non-economic relations among organizations shaped exchange relations and institutional change and raised issues about the nature of channel management and coordination. Mallen (1967) book or readings includes a section on vertical relations including vertical price and power relationships. The latter includes extracts from Palamountain's (1955) study of the politics of distribution, 
Galbraith's (1956) theory of countervailing power, as well as Mallen's (1963) own article on conflict and cooperation in channels. Other articles that appeared about the same time were by Stern (1967) on channel control and Sturdivant and Granbois (1968) on channel interactions.

Assael $(1967,1968)$ and his colleagues carried out an important set of industry case studies on conflict in channels, focusing on the role of trade associations in conflict resolution. But it was Louis Stern's (1969) book Distribution Channels: Behavioral Dimensions, that galvanized research on the behavioral dimensions. While researchers such as Alderson had described some of the behavioral processes within and between firms in marketing channels, Stern and his collaborators focused our attention clearly, for the first time, on some of the key dimensions involved and identified directions for research ${ }^{8}$. This directly or indirectly inspired a new generation of marketing academics to focus on these behavioral dimensions.

Stern's book took a social systems perspective on channel networks and focused on the roles and relations among firms in terms of role theory, power, conflict and communication. The book included original articles summarizing the literature related to each of these dimension and applying it to the inter-organization context. In addition, it included a number of important articles describing relevant theories and studies of inter-organization relations from disciplines such as sociology, social psychology and politics, including work by Palamountain (1955), Ridgeway (1957), Kreisberg (1955) and Wittreich (1962). The original articles were the foundation for several doctoral theses at Ohio State University, which later became among the first empirical studies of interfirm relations reported in the marketing literature. Elsewhere, other empirical studies of behavioral dimensions began as will be described in subsequent sections.

Stern's book opened up a vast new literature to inform our theories of interfirm relations in channel networks, going beyond the predominantly applied economics frameworks then dominating marketing 
theories. It also heralded the beginning of an era of empirical research to test the theories and hypotheses arising from applying this literature to channel networks. The concepts and theories employed had obvious relevance to the study of interfirm relations. Theories of roles, power, conflict and communication may have had their origins in other contexts, such as interpersonal, intraorganization and community relations but were equally applicable to the inter-firm context and were a fruitful source of new ideas.

What was less directly transferable were the measurements and research methodologies used in other contexts. Marketing had to set about developing its own measures of these dimensions and the causes and consequences of them. This gave rise to a series of papers in the marketing literature in which researchers developed and refined concepts and theories as well as measures of constructs. The initial focus was on the concepts of power and conflict and a review by Gaski (1984) reported 25 empirical studies of power and conflict carried out in the 1970s. ${ }^{9}$ While a focus on power-dependence and conflict dominated research, other dimensions that were to assume more prominence in the future began to be studied, such as satisfaction (Lusch 1977, Wilkinson 1979), performance effects (e.g. Pearson and Monoky 1973) superordinate goals (Hunger and Stern 1976) and network characteristics (Wilkinson 1976).

Channels research was more problematic than, say, consumer research, in that organizations were not easily represented in the classroom by students. Instead, researchers had to seek the cooperation of people working in actual organizations to carry out their studies. This led to a number of problems concerning accessing respondents as well as concerns about the reliability and validity of measures and results. The problems encountered included: the absence of established measurement scales; the general state of development of measurement theory and scale development in the marketing discipline at the time; the often low response rates; the problem of drawing inferences from samples drawn from specific industry contexts; 
and the problem of who to interview. Nevertheless, important strides were taken in getting the subject interfirm relations firmly on the research agenda and progress was made in the development of measures as researchers learned from earlier studies and borrowed items and scales.

Towards the end of the 1970s, the first attempts were made to develop general conceptual models of interfirm relations by Robicheaux and El-Ansary (1976) and Cadotte and Stern (1979) and the first marketing channels textbooks appeared by Mallen (1974) and Walters (1977), followed by the first edition of Stern and El-Ansary's text in 1982. A review of the literature also appeared (Gattorna, 1978) and the American Marketing Association published the first annotated bibliography (Michman et al 1976).

The focus of research in these years was limited in several ways, as became clearer later. The dominance of power and conflict studies was such that research was not considered successful unless conflict and power was found to be present. This led to a focus on those industries and relations where conflict and power plays are more likely, as in the car industry and franchisor-franchisee relations. The studies were also in the main restricted to survey type studies, often by mail, with perhaps some exploratory interviews preceding the development of the research instrument. The studies usually relied on single informants, focused on only one partner in the relationship and on relations at one level in the channel network. Case studies, experiments, simulations or observational studies were far less common (for exceptions see Dwyer 1980, Hunger and Stern 1976, Stern et al 1973). 


\section{0s: The Second Wave of Behavioural Studies}

After the initial studies a new generation of researchers added to the pool of academics researching in the area. These were often the doctoral students of the first wave of researchers who had now secured an academic post and were working on additional studies. Researchers from the USA as well the European based Industrial Marketing and Purchasing Group (IMP) and researchers in Australasia, began to develop their own research agendas. These developments are described in this and the next two sections.

Developments occurred in research methodology and in the dimensions of relations being studied. At the beginning of the decade an important study was reported by Phillips (1981) that tackled the problem of multiple informants in interfirm relations research. He showed that the perceptions of a relationship varied across different informants in an organization. This was seen as threatening the validity of much of the work that had been done, leading to further discussion in the literature (e.g. John and Reve 1982). Researchers started to ask questions such as: Which informant's perspective was correct? How do you combine the perspectives of different informants? It affected the conduct of subsequent studies in that attempts were made to use multiple informants or at least to justify why the informant used was the most knowledgeable or appropriate.

This issue also demonstrated another aspect of interorganization relations - that they are multiplex, involving personal as well as business relations and interactions between many people in the organizations involved, including buying and sales personnel, technical people and management. This suggests that there is not necessarily one "real" relationship to be discovered, imperfectly, through the eyes of different informants, so much as many realities that shape interactions within the relationship and within the participant organizations. 
An underlying core relationship character, that is reflected to some extent in each type of cross organization interaction may exist but it is difficult to measure as it involves using multiple informants from both sides of the relationship. Anderson and Narus (1990) presented a method for incorporating the perceptions of a such a mix of informants into the development of a core relationship measure, but most researchers continued to use single informants due to time and cost considerations. Also, for smaller firms or business units, there often was only one appropriate informant.

Measurement methodologies became more sophisticated, as did the methods for estimating connections between theoretical constructs - the era of structural equation modeling began. Marketing researchers started to catch up with and even contribute to advances in measurement theory, scale development and causal modeling. As a result, multi-item scales with acceptable psychometric properties were developed for a number of dimensions of interfirm relations that could be used by researchers.

In terms of theory, researchers started to explore additional dimensions of interfirm relations, integrated them into more comprehensive models of relationships (e.g. Anderson and Narus 1984) and sought insight from developments taking place in other disciplines. A senior academic at a conference once described a stage in the development of consumer behavior theory as the "theory of the month club" in which new theories or explanatory concepts were regularly introduced into the literature. In channel network research a similar pattern emerged which we could characterize as the "dimension a month club." The number of dimensions studied expanded (see Table 4) from the dominant focus on power-dependence and conflict to include satisfaction, cooperation, trust, commitment, continuity, reciprocity, communication, formalization, centralization, closeness-distance, opportunism, performance, comparison level with alternatives $\left(\mathrm{Cl}_{\text {llt }}\right)$ etc. 
The dimensions of power and conflict were refined to distinguish more clearly between the sources and uses of power (e.g. Frazier and Sommers 1986, Gaski and Nevin 1985), the consequences of power use for the target and user (Anand and Stern 1985, Kale 1986) and conflict management processes (e.g. Schul et al 1983) ${ }^{10}$. The 1980 s also saw the birth of specialized journals devoted to channel and business networks such as the Journal of Marketing Channels and the Journal of Business to Business Marketing

More systematic conceptualizations and studies of the dimensions of relationship environments appeared (e.g Achrol et al 1983), which allowed the effect of environmental conditions to be incorporated into relationship models (e.g. Achrol and Stern 1988, Dwyer and Oh 1987). This research was also relevant to the study and comparison of inter-firm relations in diverse contexts, such as international relations (e.g. Anderson and Coughlan 1987), Just-in-Time relations (e.g. Frazier and Summers 1984) and relations in developing countries (e.g. Frazier et al 1989, Kale 1986).

\section{Transaction Costs and Economic Theory}

Economic theory regained prominence with the focus on Oliver Williamson (1975) work on transaction costs and the nature and costs of interorganization governance. John's (1984) research on opportunism was among the first to develop measures and tests of some of his key concepts. Williamson's ideas quickly became part of mainstream research in the channels area as well as in organization behavior studies generally. Many studies were conducted operationalizing and testing models based on Williamson's theories, and linking them to other dimensions of relations (see Rindfleisch and Heide 1997 for a review). In addition, forms of relationships were proposed as additional governance modes to the market-hierarchy dichotomy used by Williamson (e.g. Arndt 1989, Thorelli 1986). Principle-Agent theory (see Bergen et al 1992 for a review) was used to further develop theories of interfirm relations, as well as theories 
concerning relational contracting from law, i.e. McNiel (1980) and McCauley (1963), were incorporated into the models and studies, which added yet more dimensions and issues to research.

A broader integration of the dimensions of relations involved linking the behavioral and economic dimensions. Stern and Reve (1980) proposed a political economy framework comprising an internal and external channel polity and economy that interacted in various ways. This gave rise to various testable propositions about the factors driving channel structure and operations. Dixon and Wilkinson (1986) also integrated the behavioural and economic dimensions of channels into a common economic framework. Behavioural variables such as power, trust and conflict were interpreted in terms of coordination activities and tasks that incurred (transaction) costs, and that are subject to the same efficiencies of specialization as other activities. Governance structures and specialist intermediaries result from attempts to gain coordinating efficiencies and tradeoffs occur among the efficiencies of performing coordination versus other types of activities. These tradeoffs underlie channel structure and the kinds of specialist institutions that emerge.

Most empirical studies of inter-firm relations were cross sectional nature and adopted an essentially comparative static approach to studying relationship structure and performance. But attention began to focus also on the dynamics of relations, how they developed over time and the nature of the problems and issues at each stage. In part this came from attempts to deal with the management issues involved in relations i.e. how firms attempt to use the results of the interorganization relations studies to bring about desired change. Existing relationships are the product of previous histories of interaction between the participants and with others, and one way of seeing how better or worse performing relations came to be that way is to examine how relations develop. Hopefully, this focus would provide some insight as to how 
managers could intervene in relations to promote beneficial change. Two papers proposed stage models of the development of relations and identified the driving forces behind them i.e. Ford (1980) based on studies being conducted by the IMP group, (discussed in the next section) and Dwyer Schur and Oh (1987), based more on an analysis of theories of relationship development.

A separate but related stream of research on channel networks developing during this period is that reflected in the development of analytical models of channel structures and interactions, which was reported mainly in the journals Marketing Science and Management Science. This research is more economics based and has its origins in the early models proposed by people like Balderston (1958), Bucklin (1966), and Baligh and Richartz (1967) discussed previously. Models were developed to represent and solve various problems associated with the design and management of channel networks. These included issues such as: downstream vertical integration (McGuire and Staelin 1983); intermediary equilibrium structures (Etgar and Zusman 1981, Zusman and Etgar 1981); implicit understandings (Shugan 1985); and channel member conjectures and profits (Jeuland and Shugan 1988). No attempt is made here to review developments in this area in more detail.

Lastly, institutional studies of the structure and performance of business networks and relations in different cultural and economic contexts were undertaken, in part building on earlier work by Slater and his colleagues (e.g. Ortiz-Buonofina 1987) 


\section{Non-American Research Traditions}

During the 1970s and beyond important developments in network research and theorising were taking place in Europe and elsewhere. In this section I outline the development of the Industrial Marketing and Purchasing Group (IMP) and their research. In the following I describe research developments in Australasia.

\section{The IMP Group in Europe}

The founding fathers of thought in Europe were reading the channels literature but their orientations were different in terms of the business context they confronted, the base literature they drew on, their less direct focus on managerial implications, and in terms of the methodologies they employed.

In the early 1970s the original IMP group of researchers were young academics based in Sweden, UK, Germany, France and Italy, who had a common interest in the study of industrial marketing. They were dissatisfied with the dominant marketing paradigm of the time, which focused on consumer goods and adopted a stimulus response, arms-length approach to the customer with the seller is the active party. The business context in Europe they faced was not dominated by fast-moving consumer goods but more by business to business marketing, often across international borders and among organizations and countries with a long history. In these markets the business buyer is active as well as the seller, the customer is not an anonymous mass market but often a limited number of known organizations, and technology development and its management play a more important role. Further, business was often conducted in the context of longstanding relations among buyers and sellers. 
The literature informing the thinking of the IMP group and associated colleagues, particularly in Sweden, was less focused on economics. The organization of university business departments in Sweden and other European countries were less rigidly divided into the functional areas of business than in the US and elsewhere, resulting in a more eclectic and wider reading and sourcing of ideas outside the traditional marketing domain. As a result researcher drew more readily on behavioral theories from sociology and organization theory such as the works of Aiken and Hage (1968), Burns and Stalker (1961), Dill (1958), Emery and Trist (1965), Hall (1972), March and Simon (1959), Thompson (1967) and Woodward (1965). In economics the ideas of Edith Penrose (1959) was influential as well as Richardson's (1972) ideas about the structure of industry. Their research tradition welcomed more descriptive in-depth case studies and longitudinal studies of industrial marketing and purchasing situations and important studies of this type were conducted that informed subsequent theorizing (e.g. Hakansson, Johanson and Wootz 1976, Kinch 1987, 1993 and Liljigren 1988). There was less pressure to work out the direct management implications of any research and this climate encouraged more long term descriptive studies and general theories to be developed.

The IMP group collaborated on a European wide study of buyer-seller relations in business markets (IMP1), in which both domestic and international relations were included. The study focused on important relations, as defined by the respondents, and interviews were conducted with informants from both sides of the relationship as far as possible, using researchers from the home country of an organisation. Lengthy indepth personal interviews were conducted using mainly open ended questions, with no attempt to develop scales for particular dimensions of relations. Analysis of the results led to the refinement of the IMP approach to marketing and to a number of books and papers describing various aspects of buyer-seller 
relations (e.g. Ford 1990, Hallen et al 1991, Hakansson 1982, Turnbull and Cunningham 1981, Turnbull and Valla 1986).

An interaction approach was proposed that stressed the role and importance of often long term exchange relations between organizations as the dominant form of business (Hakansson 1982). These relations were built up over time through the economic and social/personal interaction episodes taking place among the organizations and people from each side. This resulted in substantial investments in relations, including adaptations in resources, activities and actor bonds between the organizations that created value in the relationship for both parties. Over time, the interactions taking place in a particular environmental context gave rise to a relationship atmosphere involving various interacting dimensions including power-dependence, conflict-cooperation, closeness-distance and mutual expectations, which shaped future interactions. The technology of production and use affected the kinds of interactions taking place and who was involved, in addition to the effect of other characteristics of the organizations, people and cultures involved.

Additional studies were carried out examining particular aspects of relations and interaction behaviour. These included work on the development of technology in relations (e.g. Hakansson 1989), international relations (Rosson and Ford 1982) purchasing (e.g. Hallen 1982), networks (e.g. Johanson and Mattsson 1988) and the nature and development of patterns of interaction in relationships (Liljigren 1988)

The focus of IMP research was on the role and value of relations to the parties involved, which contrasted with the more adversarial focus and concern about the dangers of excessive dependence, conflict and opportunism characterizing much debate in the channels and strategy literature in America. In a sense the IMP group focused attention on the benefits arising from what might be described as "healthy" relations in which value and assets were created through mutual adjustment and cooperation. In contrast, much of the 
channels literature focused on "sick" relations in which potential problems and conflicts had to be avoided, power resources developed and employed, transaction specific assets protected, transaction costs minimized and conflict managed (Johanson and Mattsson 1987, 4and Hunt 1995, Young and Wilkinson 1989).

The first IMP conference took place in 1984 and this became an annual event drawing researchers with like-minded interests from around the world. Further developments of the IMP groups ideas were reflected in various books and articles describing a number of studies of buyer seller relations in various international and domestic contexts (e.g. Axelsson and Easton 1992, Ford 1997, Johanson and Mattsson 1988, Turnbull et al 1996). The actors, activities, resources model of interorganization relations became more carefully articulated and extended (e.g. Hakansson and Snehota 1995). The dyadic interaction focus developed into a network focus, in which connections between relations became a central issue in addition to the structure and dynamics of the business network as a whole (e.g. Anderson et al 1994). This led to studies and theories of the way networks develop and evolve and the role played by individual relations (e.g. Lundgren 1995).

An important milestone was the second collaborative research study (IMP2), which began in the late 1980s. This had both a case study and survey component. The aim of the case studies was to explore the development of a variety of business networks using a common protocol that covered the characteristics of a focal relation and others connected to it. These cases were included in a book by Hakansson and Snehota (1995) that weaves them into a broader conceptual framework and they were also used as part of an article outlining the theoretical framework (Anderson et al 1994). The empirical survey was in part based on the IMP1 study but was far more structured and included questions about connected relations, 
giving it a more network focus. Items were included that were designed to measure particular dimensions of relationship atmosphere as well as the functions and types of connections between relations. Again the focus was on domestic and international buyer-seller relations for industrial products, that involved a supplier selling, via some kind of intermediary organization, to an "important" customer organization. As far as possible, all firms in this triad were interviewed and asked about their relations with each of the other firms. In addition, they were asked about connected relations such as the customer's customers, the supplier's suppliers and the like. This study involved cooperation in carrying out the interviews in different countries and people from other countries that were not involved in the original study joined the group, including the USA, Japan, Holland and Australia. Not all countries in the end were able to undertake the research but a substantial data base was eventually gathered covering a number of European and Asian countries. This data base has been used to study various issues related to the nature of relations and the nature and importance of connected relations (e.g. Blankenberg-Holm et al 1996, 1999) and further work is underway to refine the measures of dimensions of relationship atmosphere, to examine cross cultural measurement issues and to further develop and test various models of relationship and network behavior and performance.

The IMP group has contributed significantly to the development of theories and evidence concerning the nature and development of interfirm relations and networks in business markets, as well as to the development of methodologies for studying such phenomena. The theories emanating from this group and associated researchers have drawn widely on developments taking place in sociology, business, history and politics (e.g. Araujo and Easton, 1996). Their ideas have gradually spread, been reported in mainstream American journals and been incorporated in textbooks and commentaries on business marketing (e.g. Achrol and Kotler 1999, Anderson and Narus, 1998). 
The methodological contributions have been mainly in the refinement and justification of more qualitatively focused research methods. Case studies and historical reconstructions of events and processes have dominated much research, rather than survey based methodologies, including the use of archival material. Easton (1995) has articulated the philosophical underpinnings of the IMP approach.

As already noted, the management implications of relationship and network research have been more central to the American research tradition. The IMP perspective has been, until recently, more concerned with developing rich pictures of relations and networks and developing frameworks for understanding them. The connection to management practice is looser, with the implicit assumption that better understanding will lead to better management behavior. As a review of papers presented at IMP conferences concluded, “only very few papers analyze performance impacts" (Gemunden 1997 p 12). But in the 1990s a greater focus on the management and performance implications of their research began and this is reflected in the publication of texts for management courses and a more explicit examination of the strategic issues arising for firms participating in complex networks of relations (e.g. Ford et al 1998)

\section{Australasian based Relations and Network Studies}

A number of early studies of power, conflict and satisfaction in interfirm relations were conducted in Australia, with several of them included in Gaski's (1984) review. Several studies were conducted by Wilkinson (see Gaski's 1984 review paper), as well as others by Guilhaus (1978, 1979, 1980a, 1980b) ${ }^{11}$ and Glaser and Halliday (1984). Other research foci downunder include: studies of the macro structure and development of trade in an economy carried out by Layton (1981a, 1981b, 1984), building earlier work of Cox Goodman and Fischandler (1965); and Layton's (1985) work on the role of distribution linkages in economic development, building on Slater's (1968) early work in Latin America. 
The empirical studies of interfirm relations were broadened into the Interfirm Relations Research Project, that was designed to develop a comprehensive data base of interfirm relations from a variety of industry, cultural and interfirm contexts (Wilkinson and Young 1989, Young and Wilkinson 1997). Standardized questionnaires for buyers and sellers were developed covering a variety of relationship dimensions that were refined over successive waves of data gathering and used multiple informants. The research led to the development of a dancing metaphor for characterizing interfirm relations, emphasizing the interactive processes in a relationship, which complemented the structural bonds orientation implied by the commonly used marriage metaphor (Wilkinson and Young 1994).

Another research theme emerging in Australia in the 1980s was an interest in the dynamics and evolution of network structures and their environments. This work was stimulated in part by Fred Emery, the renowned systems theorist (e.g. Emery and Trist 1965) joining for a time the marketing faculty at the University of New South Wales. Drawing on emerging concepts in systems theory, including dissipative structures and process models of structural evolution, theories of the environment and channel network evolution were developed (e.g. Glaser 1985, Wilkinson 1990). This led to later work on modelling the evolution of networks (e.g. Easton et al 1987, Wilkinson et al 1999).

Interest in the study of interfirm relations and networks in Australasia gradually increased. In the early 1990s a collaborative relationship was established with the IMP Group, which led to the use of IMP2 research instruments to develop a database of interfirm relations and networks involving Asian firms, and the hosting of an IMPOZ conference and doctoral consortium in 1997. Another development was the hosting of the first International Colloquium on Relationship Marketing by Monash University in 1993, drawing contributors from America, Europe, Scandinavia as well as Australasia, with the papers published 
in a special issue of the Asia-Australia Marketing Journal in $1994 .{ }^{12}$ In general, research on channel and business networks and relationsships became a regular theme at the annual Australia New Zealand Marketing Academy conferences and in 1998 a second International Relationship Marketing Colloquium was held at the University of Auckland in New Zealand in 1998 and an IMPOZ workshop was held in early 2001.

Several types of research areas have emerged out of this growing interest in the study of relations and networks in marketing. Here I can only mention a few. One example is the work by Brodie and Coviello (e.g. Brodie et al 1997, Coviello et al 1997) and their colleagues in developing an instrument to measure the extent to which firms use transactional versus relational approaches to marketing. Four types of approaches to marketing are measured, i.e., transaction, database, interaction and network marketing, and they have assembled a collaborative group of researchers around the world to collect data about the marketing approaches of firms in different cultural and industrial contexts. Other examples of work in the area include: studies of the role of interfirm and interpersonal networks in the development and internationalization of firms and industries (e.g. Coviello and Munro 1997, Coviello and Martin 1999, Welch et al 1996, 1998, Wilkinson et al 2000); and studies of marketing relationships and networks in various international and domestics settings (e.g. Ahmed, Patterson and Styles 1999, Mavondo and Rodrigo 2001, Sharma and Patterson 2000).

\section{0s - Relations, Networks and Methods}

In the 1990s there has been a greater coming together of the various research traditions. The emergence of relationship marketing in industrial and consumer markets, the linking of services marketing to the study of 
relations and networks, and the greater emphases on cooperative as opposed to adversarial relations has resulted in an explosion of interest in the area of relations and networks.

In terms of research output Table 4 shows the growth in number of network related studies published in the Journal of Marketing and Journal of Marketing Research since the 1970s. Issues related to the more cooperative aspects of channel and network relations have gained more prominence in the 1990s. Trust, communication, commitment and value have become focal dimensions in attempts to understand how cooperative, longer term relations emerge, their benefits and the way they can be managed (e.g. Anderson 1995, Gesykens et al 1998, 1999, Hakansson and Snehota 1995, Kalwani and Narayandas 1995, Morgan and Hunt 1994, Webster $1992^{13}$ ). More comprehensive models of interfirm relations have been proposed and tested involving several dimensions of relations (e.g. see Iacobucci and Hibbard 1998 for a review) and typologies of relations based on the mix of cooperative and competitive elements have been empirically developed (Cannon 1999, Young and Wilkinson 1997). Meta-analyses have been conducted of empirical studies of relation dimensions such as trust and satisfaction (e.g. Geyskens et al 1998, 1999, Iacobucci and Hibbard 1998), as well as more general reviews of research on particular dimensions (e.g. Bergen et al 1992, Dahlstrom and Dwyer 1993a 1993b, Frazier and Antia 1995, Rindfleisch and Heide 1997). These overviews of the literature point to gaps, contradictory findings and deficiencies that call for additional research.

\section{Insert Table 4 about here}

Researchers in the 1990s began focusing more attention on network dimensions, as opposed to dyadic relations in isolation (e.g. Alajoutsijarvi et al 1999, Anderson et al 1994, Achrol 1997, Achrol and Kotler 1999, Hakansson and Snehota 1995, Iacobucci 1996). Studies were conducted concerning the 
connections between relations (e.g. Blankenberg-Holm et al 1996, 1999), relationship portfolios (e.g. Turnbull et al 1996, Olsen and Ellram 1997), network evolution (Lundgren 1995, Easton et al 1997), network development and facilitation (Welch et al 1996, 1998), the creation of value (e.g. Anderson et al 1994, Ghosh and John 1999, Wilson and Jantrania 1996) and firms' network competence (Ritter 1999).

Increased research interest has been shown in the nature and role of relations and networks in non-western, particularly Asian, cultures where such features are assumed to play a prominent role in business (e.g. Journal of Marketing Channels 1994, Ambler et al 1999) These studies have suggested additional dimensions of relations, such as obligational contracting, guanxi and face, and contributed to the development and refinement of existing concepts (e.g. Johnson et al 1993). Studies of channels and networks in less developed countries have also revealed how these structures are linked to economic development (e.g. Olsen and Granzin 1990). Such studies link back to earlier work by Slater and others and have important policy implications for government and multilateral agencies. Lastly, historical studies reveal the pattern of forces producing existing network structures and the impact of different historical, cultural and economic circumstances (e.g. Keep et al 1998).

Lastly, new technologies have been used in the study of business networks that allow issues not previously addressed to be focused on. These include network analysis methods (Iacobucci 1992, 1996) and new ways of explaining and modeling the evolution of business and channel networks as complex self-organizing adaptive systems (Easton et al 1997, Wilkinson et al 1999). These methods are likely to take on greater importance in the next millenium as awareness of these methods spreads and easier to use computer programs are developed. 
Lastly, additional analytical models of aspects of channel networks have been proposed, focusing on issues including: price competition (Choi 1991); channel power relations (Messinger and Narasimhan 1995); channel coordination and pull promotions (Gerstner 1995); channel management (Lee and Staelin 1997); and manufacturer allowances (Kim and Staelin 1999).

\section{Where are we now?}

At the start of this review I posed five fundamental questions we seek answers to in order to understand the nature, structure, operations and management of business networks or channel systems. Let us now reconsider them in the light of the foregoing review.

\section{Why are networks structured the way they are?}

Tremendous progress has been made in understanding the forces driving network structure. The various principles underlying the economies of specialization among and within firms have been identified as well as the inherent tradeoffs among them. We have moved from simplistic descriptive accounts of specialist organizations and their functions to deeper principles that underly the efficiencies of organizations specializing in activities of different scales and scopes. Williamson (1981) has termed these types of efficiencies aggregation economies and there are many ways in which activities can be aggregated to gain efficiencies. The include: aggregating the same activity at a point in time (economies of scale) or over time (learning curves); aggregating activities with common inputs (economies of scope); aggregating complementary activities (administrative efficiencies); aggregating transactions at a point in time (bulk transactions) or over time (long term relations); and aggregating risks and uncertainty at a point in time 
(pooled risk, massed reserves) or over time (futures markets, adaptive strategy and the learning organisation).

These economic principles extend beyond a narrow conceptualization of marketing channels and networks as beginning "after production" and linking production to consumption, but relate to the entire value production system and to the way it can be divided up into various intermediate assortments of activities, operating both in series and parallel, to gain various efficiencies. We can, in principle, unpack a given network structure and identify the efficiencies underlying the division of tasks, and activity assortments involved within and between firms. In this way we are able to unravel the mysteries of extant networks in terms of the economies of specialization and aggregation. The principles apply equally to the management and coordination tasks as well as to production and distribution tasks (see Dixon and Wilkinson (1986) for a fuller explanation), which leads us into the second fundamental question.

\section{How are business networks and channel systems coordinated, controlled and managed?}

Coordination and management activities are often treated differently to other production, marketing and distribution activities. They refer to the so-called behavioral dimensions of channels and networks and are analyzed more in terms of psychological, political, social and sociological dimensions rather than economic principles. However the rebirth of transaction cost economics under the primary leadership of Oliver Williamson has brought the behavioral dimensions closer to the other dimensions. We can now interpret management and coordination tasks in terms of economic principles of efficiencies of specialization and aggregation. Governance structures are specialized institutional arrangements that arise depending on the scope and scale efficiencies arising. Long terms contracts, employment contracts, relational or obligational contracting, the development of trust and idiosyncratic or relationship specific assets are only possible if 
transactions among those involved are aggregated over a wider range or scope of activities (e.g. in employment or franchise contracts) and/or over time (i.e. the frequency of transactions and duration of a relations). The efficiencies of elaborate governance mechanisms also depend on the extent of the coordination tasks involved i.e. their scale and scope. Some transactions are more routine, immediate and homogeneous, as in commodity trade, FMCGs and low involvement items, whereas other are more complex and time consuming. The latter include situations where uncertainty levels are higher, there are hidden or credence attributes that can only be detected after purchase and use or not even then, when purchase cycles and investment commitments involve lengthy time periods and the environment is more dynamic and uncertain (e.g. high technology markets).

In principle this understanding permits us to analyze existing network structures and governance systems in terms of their efficiency and effectiveness.

An existing network structure may be understood in terms of the tradeoffs within and between the efficiencies of alternative operating and governance structures. In principle we can identify the most efficient division of tasks at a point in time and over time for carrying out a set of production, marketing and distribution tasks, including taking into account the various tradeoffs involved. Logistics and physical distribution systems analysis have produced models to do this. But an efficient operating system cannot be considered in isolation from its governance structure, the two are different aspects of the one system. What may be the most efficient governance system may conflict with the most efficient operating systems and so tradeoffs at this level occur. Some of the marketing science type analytical models, starting with the earlier work of Balderston, Baligh and Richardtz, attempt to develop simplified models of networks that show the interplay of the economic principles underlying network structures. How such tradeoffs actually occur, 
what channel systems actually arise from those that are possible, how efficient and effective they are, and whether we can control their development is the subject of the remaining fundamental questions.

But, before we move on to consider what we have learned about the answers to these other questions, it should be noted that the efficiency of a networks structure, including its governance structure is not static. Over time firms learn about each other and their broader environment. Actor bonds develop which act as forms of governance mechanisms, or at least affect the efficiency and possibility of alternative governance mechanisms.

\section{Development and Evolution of Networks}

While we may be able to, in principle, unpack an existing network in terms of the efficiency and effectiveness of its operating and governance structure and the tradeoffs involved, this does not explain how a given channel structure came to be and how it will change over time. Economic theory and most models and theories of business networks have focused on comparative static analysis. The focus is on the nature of economic equilibria and the factors affecting such equilibria. Generally, it is assumed that in the long term, under competitive conditions, an efficient equilibrium structure will somehow emerge and, if conditions change leading to another equilibrium, the network will move to that equilibrium in the long run. The trouble is we do not know how long the long run is, whether a network will ever get to such an equilibrium and how many possible equlibria there are.

We are only recently beginning to make headway in this area of analysis of networks. Previous attempts to deal with the processes of change and development were largely descriptive accounts of patterns of change and general accounts of innovation and diffusion processes. We were unable to model the dynamics and evolution of business networks except under very simplified conditions. The most significant attempts are 
those conducted early on by Balderston, followed by those of Forrester and Bowersox. But recent developments in the science of complexity and the ability to model the behavior of complex adaptive systems using agent based computer programming techniques open up new ways of developing our ideas. I take this issue up in the section of future research areas.

\section{Identifying and Creating Optimal or Better Performing Networks}

Our ability to control and manage the development of networks is limited although the marketing literature has tended to assume away the problem. Assumptions of the existence of a channel or network leader or captain that is capable of directing the operations and structure of a network allow us to develop normative models of networks based on our understanding of the forces underlying network structure and efficiency. But networks are not usually like this, they are more loosely coordinated and directed systems in which various members are trying to exercise control over others and are at the same time subject to the influence of others. In this situation the outcomes are complex and may not easily or even in principle be traced to the actions of individual network members (March 1996). As already noted, we are only now beginning to develop models to try to understand the dynamics and evolutionary processes involved and how they could be influenced. Hence I must conclude that at present we are not capable of designing optimally performing network systems, except in simple static situations.

\section{How Should Firms Operate in Business Networks?}

The understanding of networks as complex adaptive systems undermines any simple notions of channel and network management. Many studies have been done to model and measure aspects of the interfirm coordination and control process and these provide management with insight as to how to manage these activities. These studies have shown us the way different factors impact on firms' power, dependence and 
control, and how this power may be used and with what effect. We know a lot about the sources of conflict and how different strategies impact on conflict and it management. More recently research has shown how trust and commitment develop in relations, how this affects attitudes and performance, and the value of longer-term relations. But I believe it is fair to say that theories of channel and network management up to now have focused mainly on the situation of a powerful actor trying to get others to do what it wishes and dealing with the conflicts that arise. There is far less treatment of the less powerful actor and how they should respond to the actions of a powerful actor, yet for all power wielders there must be power subjects. The view of networks I see we are heading to is more complex - one in which no one network member is in charge, controlling and directing the network (Wilkinson and Young, forthcoming). Instead, power in a network is more diffused and firms are as much the subjects of influence as they are the influencees. A self-organizing process is at work in which individual firms sense, learn, respond and adapt to their positions in a network. They only have limited knowledge of the actions of others and the consequences of their own actions. Firms act both individually as well as in collaboration with other organizations in their network, including suppliers, distributors, customers, complementors and competitors. We may continue to search for magic bullets or new means of controlling the self-organising processes in networks to our advantage, but developments in complexity science show us that this is futile. It may be necessary to continue to believe in such magic bullets and to continue to search for them because this contributes to a healthy self-organizing process. But it is rather like searching for the mythical butterfly in South America that chaos theorists talk about, whose wing flapping caused tornadoes to move in North America, and then trying to control its wing flapping! I return to these issues in the final section on future research directions. 


\section{Conclusions and Future Research Directions}

I have outlined in broad terms some of the main streams of research leading to the current state of thinking and research regarding interfirm relations and networks. We now have a substantial literature and body of research. While much remains to be done we have moved far from the earlier descriptive or prescriptive writing with little underlying theory. We have developed both the economic dimensions of channel and network structure as well as the behavioral dimensions and made attempts to integrate them. We have develop and tested sophisticated measures of many aspects of channel and network structures, operations and environments. We have proposed and tested complex path models among the dimensions of relationships and their performance and have begun to accommodate network level factors into our theories and research. The dynamics and evolution of channels and networks has begun to be more systematically studied and modeled drawing on developments in complexity science. In short we have come a long way. The history reveals something about the way research develops as an intellectual, professional and social process. Thus we see the echoes of ideas first developed in the early part of the century appear in much later research and the way they are further developed as new tools and theories become available. One example is the development of analytical and evolutionary models in the 80 s and 90 s that represent more sophisticated and advanced forms of the models proposed in the 1950s and 60s by Balderston, Baligh, Bucklin and Richartz. A second example is the way research on behavioral dimension starting in the 1970s echoes some of the concepts and issues proposed much earlier by Commons and Coase.

Third, the sociology of science is revealed in the way ideas and approaches are developed and championed in particular regions and groups, such as the work of Alderson and the Wharton School in the 50s and 60s, 
the group centered around Stern at Ohio State and later at Northwestern, the development of the IMP group and of the researchers in Australia based at the University of New South Wales. We can see how common interests, cultures, stages in the academic life cycle, as well as location/isolation shape the development of academic agendas. We can see the way the environment and intellectual traditions of different cultures shape the kinds of problems and issues focused on and the methods used - compare the IMP group to the North American research tradition. And we can notice the gradual diffusion of ideas from different groups through the academic community, leading to cooperative research, joint publications and conferences.

Gradually, marketing researchers have carved out distinctive niches for themselves in the study of channel and business networks. They have borrowed heavily from other disciplines in developing and refining their theories, models and methods. Economics dominated at first but as the behavioral disciplines matured, marketing increasingly drew on them and on the field of organization studies generally. But economic theories were not ignored and, as they developed, they have been incorporated into marketing theories, such as the work of Oliver Williamson.

This is as it should be, given the multi-dimensional nature of the area of study. But marketing scholars have made substantial contributions of their own in understanding the character and formation of business relations and networks and to the development of research methodology. This has provided a basis for developing normative theories of how firms should try to cope with the problems of managing their relations with other network members and has shown the limits of an individual firm's ability to do so.

\section{Future Research Directions}


As already noted, a number of articles in the 1990s have reviewed developments in theory and research in this area and suggested areas for further work. I will not attempt a detailed accounting here but will point to a few areas I believe will become important research areas in the next millenium based on the literature review described.

1) Interactions among Relationship Dimensions. The primary focus to date has been on identifying the causal sequence of effects among relationship dimensions ${ }^{14}$. One challenge is to incorporate feedback effects into the models, not just unidirectional causation. This presents methodological challenges and calls for dynamic models and time series analyses. An alternative approach proposed by Young and Wilkinson (1997) is to see relationships and networks gravitating to some form of balance among the various objectives, beliefs, attitudes and behavior taking place, analogous to the way people seek a balance among the various cognitions and responses making up their personality. Consonance, or balance, means that the various dimensions are mutually consistent and reproduce each other over time - a form of dynamic equilibrium or attractor for the relationship or network. This does not imply that the beliefs, attitudes and behavior are the same for each relationship participant, just that they complement each other. Dissonance implies a lack of balance and tension which drives changes until consonance results. This view calls for a different research approach to causal modeling. We need to identify the types of attractors that can arise for relationships and networks, to examine their characteristics and performance implications and the paths leading to them.

2) Connected Relations. Much research has focused on dyadic relations in isolation or in terms of general environmental characteristics. But networks comprise connected relations. The nature and impacts of connected relations on a focal relation or firm have begun to be analyzed (e.g. Anderson et al 1994, 
Wilkinson and Easton 1997) and studies have shown the significant effects of connected relations (e.g. Blankenburg-Holm, et al 1996, 1999). Additional research focusing on this issue is called for as we focus on the network as the unit of analysis.

3) Network Analysis. Iacobucci $(1992,1996)$ introduced network analysis methods into channel analysis but researchers have made limited use of them to date. Research in other disciplines has shown how such methods lead to the identification of important network dimensions shaping network member behavior and performance (e.g. Burt and Janicik 1996). These include the impact of role and position on behavior and performance, the impact of the characteristics of connected firms on a focal firm, as well as the existence and impact of subgroups and cliques in the network. This calls for gathering data on networks of interconnected firms and relations rather than samples of independent dyadic relations.

4) Simulation and Modeling of Complexity. Advances in computer simulation and modeling techniques offer opportunities to build models to study the dynamics and evolution of business networks in ways that were previously impossible. As Langton (1996), one of the pioneers of these new types of models, summarized the underlying rationale: "it extends the empirical database upon which the theory of the discipline is built beyond the often highly accidental set of entities that nature happened to leave around for us to study."(p iv). Business networks are complex adaptive systems in which order emerges in a bottom up self-organizing way, through the micro interactions taking place (e.g. Arthur et al 1997, Easton et al 1997, Wilkinson et al 2001). The study of such systems, or what is termed complexity, is being increasingly recognized as a new and important focus for research. For example, a recent issue of the journal Organization Science (Anderson, P. 1999) was devoted to an examination its potential role in the study of organizations. In addition, the methods are being taken up by business as they seek improved 
ways of understanding and controlling the complex business networks of which they are a part (e.g. Axelrod and Cohen 1999, Ernst and Young 1998, Roy 1998).

Opportunities exist for researchers to study the dynamics and evolution of business and channel networks by employing these theories and techniques. Some of the existing analytical models of channel structure and operations could be made dynamic and further explored by means of this approach. Early attempts to do this were limited by the resources and programs available (e.g. Balderston and Hoggatt 1962, Bowersox et al 1972).

Modeling channels and business networks as complex adaptive, self-organizing systems focuses attention on the management problems of firms operating in such systems (e.g. Achrol 1991, 1997, Hakansson and Ford, forthcoming, Wilkinson and Young, forthcoming). While firms may attempt to organize and direct the networks of which they are apart, no firm controls the network as a whole. Firms are as much subject to the control of others as they are in control of them. This means that the outcomes of a firm's actions are uncertain in a fundamental way, as they depend on the behavior and reactions of others over whom they limited if any control. In this situation network management is not simply a matter of controlling and directing the behavior of other network members, it is more about participating, responding and learning about the problems and opportunities that emerge (Axelrod and Cohen 1999). There is a need to develop better theories about how firms do and should behave in such complex adaptive networks in order to coproduce better individual and network performance.

In conclusion, it seems clear that the road ahead is not simply a normal science type of tidying up process. To be sure, some issues concerning the nature and operations of channel and business networks are of this kind. But there are also opportunities to break new ground by exploring truly dynamic network level 
theories and methodologies that will broaden our horizons and challenge existing notions of channel and network management. 


\section{References}

Achrol, Ravi S. (1991), "Evolution of the Marketing Organization: New Forms for Turbulent Environments..” Journal of Marketing, 55 (October), 77-93.

Achrol, Ravi S. (1997), "Changes in the Theory of Interorganizational Relations in Marketing: Toward a Network Paradigm." Journal of the Academy of Marketing Science, 25 (1), 56-71.

Achrol, Ravi S. and Stern Louis W. (1988), "Environmental Determinants of Decision-Making Uncertainty in Marketing Channels." Journal of Marketing Research, 25 (February), 3650 .

Achrol Ravi S. and Kotler Philip (1999), "Marketing in the Network Economy." Journal of Marketing, 63 (Special Issue), 146-163.

Achrol, Ravi S., Singh and Reve, Torge (1983), "The Environment of Marketing Channel Dyads: A Framework for Comparative Analysis.” Journal of Marketing, 47 (October), 55-67.

Ahmed, Farid, Patterson, Paul and Styles, Chris (1999), "The Determinants of Successful Relationships in International Business.” Australasian Marketing Journal, 7 (1), 5-21.

Aiken, M. and Hage J. (1968), "Organizational Interdependence and Intra-organizational Structure.” American Sociological Review, 33 (6), 912-930.

Alajoutsijarvi, Kimmo, Moller, Kristian and Rosenbroijer, Carl-John (1999), "Relevance of Focal Nets in Understanding the Dynamics of Business Relationships,." Journal of Business to Business Marketing, 6 (3), 3-36.

Alderson, W. (1950), "Marketing Efficiency and the Principle of Postponment." Cost and Profit Outlook, 3 (September), 424.

Alderson, Wroe (1957), Marketing Behavior and Executive Action. Homewood, Ill: Irwin.

Alderson, W. (1965), Dynamic Marketing Behavior. Homewood, Ill: Irwin.

Alderson, Wroe and Reavis Cox (1948), "Towards a Theory in Marketing." Journal of Marketing, 13 (October), 137-152.

Ambler, Tim, Styles, Chris and Xiucun, Wang (1999), “The effect of channel relationships and guanxi on the performance of inter-province export ventures in the People's Republic of China." International Journal of Research in Marketing, 16 (February), 75-87.

Anand, Punam and Stern, Louis W. (1985), "A Social-Psychological Explanation of Why Marketing Channel Memebers Relinquish Control.” Journal of Marketing Research, 22 (November), 365-376. 
Anderson Erin and Coughlan, Anne T. (1987), "International Market Entry and Expansion via Independent or Integrated Channels of Distribution.” Journal of Marketing, 51 (January), 71-82.

Anderson, Erin and Weitz, Barton (1992), "The Use of Pledges to Build and Sustain Commitment in Distribution Channels." Journal of Marketing Research, 29 (February), 18-34.

Anderson James C. (1995), "Relationships in Business Networks: Exchange Episodes, Value Creation and Their Empirical Assessment." Journal of the Academy of Marketing Science, 23 (4), 346-353.

Anderson, James C., Hakan Hakansson, and Jan Johanson (1994), "Dyadic Business Relationships Within a Business Network Context." Journal of Marketing, 58, (October), 1-15.

Anderson, James and James Narus (1984), "A Model of the Distributors Perspective of Distributor-Manufacturer Working Relationships." Journal of Marketing, 48 (Fall), 6274. .

Anderson, James and James Narus (1990), "A Model of Distributor Firm and Manufacturer Firm Working Partnerships,." Journal of Marketing, 54, (January), 42-58. .

Anderson, James and James Narus (1998), Business Market Management: Understanding, Creating and Delivering Value, New York Prentice-Hall.

Anderson, Philip (1999), "Complexity Theory and Organization Science." Organization Science $10(3), 216-232$.

Arthur, W. Brian, Steven N. Durlauf, and David A. Lane, eds. (1997), The Economy as a Complex Evolving System II. Reading Mass.: Addison Wesley.

Arndt, Johan (1979), "Toward a Concept of Domesticated Markets." Journal of Marketing, 43 (Fall)69-75.

Araujo, Luis and Easton Geoff (1996), "Networks in Socioeconomic Systems: A Crtical Review." in Dawn Iacobucci, ed. Networks and Marketing. Thousand Oaks:CA Sage Publications, 63-107.

Aspinwall, Leo V. (1956), "Parallel Systems of Promotion and Distribution." Cost and Profit Outlook (October) (Also in Leo V. Aspinwall (1961), Four Marketing Theories. Bureau of Business Research, Boulder Co: University of Colorado 1961).

Assael, Henry ed. (1967), The Politics of Distributive Trade Associations: A Study of Conflict Resolution. Hempstead, New York: Hofstra University.

Assael, Henry (1968), The Political Role of Trade Associations in Conflict Resolution, Journal of Marketing, 32 (April), 21-28. 
Axelrod, Robert and Michael D. Cohen (1999), Harnessing Complexity, New York, The Free Press.

Axelsson, B and G. Easton eds. (1992), Industrial Networks: A New View of Reality. London, Routledge. .

Balderston Frederick E. (1958), "Communication Networks in Intermediate Markets." Management Science, 3 (January), 156-171.

Balderston, Frederick E. and Hoggatt, Austin C. (1962), Simulation of Market Processes Berkeley, California: Insitute of Business and Economic Research, Special Publications No 1.

Baligh, Helmy H. and Richartz, L. E. (1967), Vertical Market Structures. New York: Wiley.

Bartels, Robert (1962), The Development of Marketing Thought. Homewood,Ill. Richard D. Irwin.

Bartels, Robert (1963), Comparative Marketing: Wholesaling in Fifteen Countries. Homewood, Ill: Irwin.

Bergen, Mark, Dutta, Shantami, and Walker, Oliver C. Jr. (1992), “Agency Relationships in Marketing: A Review of the Implications and Applications of Agency and Related Theories." Journal of Marketing, 56 (July), 1-24.

Blankenburg-Holm, Desiree, Kent Eriksson and Jan Johanson (1996), "Business Networks and Cooperation in International Business Relationships,." Journal of International Business Studies, 27 (5), 1033-1053.

Blankenburg Holm, Desiree, Kent Eriksson and Jan Johanson (1999)"Creating value through mutual commitment to business network relationships." Strategic Management Journal, 20 (5), 467-486.

Boddewyn, J.J. and Hollander, S. C. (1972), Public Policy Toward Retailing, Lexington. Mass: Lexington Books.

Boulding, K. (1952), “Toward a General Theory of Growth.” Canadian Journal of Economics and Political Science, 19 (August), 326-340.

Bowersox D.J. (1972), "Planning Physical Distribution Operations with Dynamic Simulation." Journal of Marketing, 36:1 (January), 17-25 .

Bowersox, Donald J. Helferich, Omar K., Marien, Edward J., Gilmour, Peter, Lawrence, Michael L., Morgan, Fred W. and Rogers, Richard T. (1972), Dynamic Simulation of Physical Distribution Systems. East Lansing, Michigan State University.

Breyer, Ralph F. (1924), The Marketing Institution. New York ,McGraw-Hill. 
Breyer, Ralph F. (1949), Quantitative Systemic Analysis: Channel and Channel Group Costing. Philadelphia: published by the author.

Brodie, R. J., Coviello, N.E., Brookes, R.W. and Little, V. (1997), "Toward a paradigm shift? An examination of contemporary marketing practices." Journal of Marketing Management, 13 (5), 383-406.

Brown, James R. \& Ralph L. Day, (1981), "Measures of Manifest Conflict in Distribution Channels", Journal of Marketing Research, 18 (August), 263-74.

Bucklin, Louis P. (1960), "The Economic Structure of Channels of Distribution.” in M.L. Bell ed. Marketing: A Maturing Discipline. Chicago American Marketing Association, 63-6.

Bucklin, Louis P. (1965), "Postponement, Speculation and the Structure of Distribution Channels." Journal of Marketing Research, 2 (February), 26-31 .

Bucklin, Louis P. (1966), A Theory of Distribution Channel Structure. Institute of Business and Economics: University of California at Berkeley.

Bucklin, Louis P. (1970), Vertical Marketing Systems, Glenview, IL: Scott, Foresman and Company. .

Bucklin, Louis P. (1971), "Trade Area Boundaries: Some Issues in Theory and Methodology." Journal of Marketing Research, 8 (February), 30-37.

Bucklin Louis P. (1972), Competition and Evolution in the Distributive Trades. Englewood Cliffs, N.J.: Prentice-Hall.

Burns T. and Stalker G. M. (1961), The Management of Innovation. London: Tavistock Publications.

Burt, Ronald and Gregory A. Janicik, (1996), "Social Contagion and Social Structure." in D. Iacobucci (ed.), Networks in Marketing. Thousand Oaks, CA: Sage Publications, 32-49.

Cadotte Ernest and Louis W. Stern (1979), “A Process Model of Interorganization Relations in Marketing Channels.” Jagdish Sheth ed., Research in Marketing: Volume 2. Greenwich, Conn.: JAI Press, 127-158.

Carson, Stephen J., Devinney Tinmothy M., Dowling, Graham R. and John George (1999), " Understanding Institutional Designs Within Marketing Value Systems,." Journal of Marketing, 63 (Special Issue), 115-130.

Cannon, Joseph P and Perreault Jr., William D. (1999), "Buyer Seller Relations in Business Markets.” Journal of Marketing Research, 36 (November), 439-460.

Chandler Jr., Alfred D. (1977), The Visible Hand: The Managerial Revolution in American Business. Cambridge, Mass.: Belknap Press. 
Choi, S. Chan. (1991), "Price competition in a channel structure with a common retailer." Marketing Science, 10 (Fall), 271-296. .

Christian, David (1991), “The Case for 'Big History."” Journal of World History, 2 (Fall), 223238.

Coase Ronald H. (1937), “The Nature of the Firm.” Economica, 4 (November), 386-405.

Commons, John R. (1934), Institutional Economics. Madison: University of Wisconsin Press.

Commons, John R. (1950), The Economics of Collective Action. Madison: University of Wisconsin Press.

Coviello, Nicole E., Brodie, Rod J. and Munro, Hugh J. (1997), "Understanding contemporary marketing: development of a classification scheme." Journal of Marketing Management, 13 (6), 501-522.

Coviello, Nicole E. and Martin Kristina A-M. (1999), 'Internationalization of Service SMEs: An integrated Perspective from the Engineering Consulting Sector." Journal of International Marketing, 7 (4), 42-66.

Coviello, Nicole E. and Munro, Hugh J. (1997), "Network Relationships and the Internationalization Process of Small Software Firms." International Business Review, 6 (2), 361-86.

Cox, Reavis, Goodman, Charles S. and Fischandler (1965), Distribution in a High Level Economy. Englewood Cliffs: NJ, Prentice Hall.

Cox, Reavis and Goodman, Charles S. (1956), "Marketing of Housebuilding Materials." Journal of Marketing, 21 (July), 36-61.

Craig, David and Gabler, Werner (1940), "The Competitive Struggle for Channel Control." The Annals of the American Academy of Political and Social Science May 84-107.

Cundiff, Edward (1965), "Concepts in Comparative Retailing." Journal of Marketing, 24 (January), 59-63.

Dahlstrom, Robert and Dwyer F. Robert (1993a), "The Political Economy of Distribution Systems:A Review and Prospectus." Journal of Marketing Channels, 2 (1), 47-86.

Dahlstrom, Robert and Dwyer F. Robert (1993b), "The Political Economy of Distribution Systems: Network Perspectives and Propositions." Journal of Marketing Channels, 2 (4), 29-41.

Dant, Rajiv and Schul, Patrick L. (1992), "Conflict Processes in Contractual Channels of Distribution." Journal of Marketing, 56 (January), 38-54.

Davidson, William R. (1970), "Changes in Distributive Institutions.” Journal of Marketing, 34 (January), 7-10.

Day, George (1996), "Using the Past as a Guide to the Future: Reflections on the History of the Journal of Marketing,." Journal of Marketing, 58 (January), 14-17. 
Dickson, Peter R. "Distribution portfolio Analysis and the Channel Dependence Matrix: New Techniques for understanding and managing the Channel." Journal of Marketing, 47 (October), 35-44.

Dill, W. R. (1958), Environment as an Influence on Managerial Autonomy." Administrative Science Quarterly, 2 (4), 409-443.

Dixon D.F. (1982), "The Historical Origin of the Channel Concept,." in Michael G. Harvey and Robert Lusch eds. Marketing Channels: Domestic and International Perspectives. Norman, OK., University of Oklahoma Press, 146-151.

Dixon D.F. (1984), “The Intellectual Heritage of Retailing,.” in A. Spranzi and J. Jacobs eds. The Economics of Distribution. Milano, Italy: Franco Angeli Editore, 751-779.

Dixon D.F. (1991), "Marketing Structure and the Theory of Economic Interdependence: Early Analytical Developments." Journal of Macromarketing, 11 (2), 6-18.

Dixon, Donald F. and Ian F. Wilkinson (1986), “Toward a Theory of Channel Structure.” In , Louis P. Bucklin and James Carmen ed, Research in Marketing: Distribution Channels and Institutions. Volume 8, Greenwich, Conn: JAI Press, 27-70.

Duddy, E. and Revzan, D. (1953), "The Holistic-Institutional Approach to Marketing." In Marketing.2nd Ed, Appendix C.

Dwyer, F. Robert, (1980), "Channel-Member Satisfaction: Laboratory Insights.” Journal of Retailing, 56 (2), 45-65.

Dwyer, F. Robert and Oh, Seho (1987), "Output Sector Munificence Effects on the Internal Political Economy of Marketing Channels." Journal of Marketing Research, 24 (November), 347-358.

Dwyer, F. Robert, Schurr, Paul H. and Oh, Sejo (1987), "Developing Buyer Seller Relations", Journal of Marketing, 51 (2)11-28.

Dwyer, F. Robert, Schurr, Paul H. and Oh, Sejo (1988), “A Transaction Cost Perspective on Vertical Contractual Structure and Interchannel Competitive Strategies.” Journal of Marketing, 52 (April), 21-34.

Easton, Geoff (1995), "Methodology and Industrial Networks in Business Marketing: An Interaction and Network Perspective." in Kristian Moller. and David Wilson eds. Business Marketing: An Interaction and Network Perspective. Boston, Kluwer 411-492.

Easton, Geoff, Ian F. Wilkinson and Christina Georgieva (1997), "On the Edge of Chaos: Towards Evolutionary Models of Industrial Networks." in Hans Georg Gemunden and Thomas Ritter eds. Interaction, Relations and Networks. Oxford, Elsevier Science, 273-293.

El-Ansary, Adel I. and Stern, Louis W. (1972), "Power Measurement in the Distribution Channel.", Journal of Marketing Research, 9 (February), 47-52. 
Emery, F.E. \& E.L. Trist (1965), "The Causal Texture of Organizational Environments." Human Relations, 18, 21-32.

Ernst and Young ed. (1998), Proceedings: Embracing Complexity Conference. Cambridge: MA, Aug $24^{\text {th }}$.

Etgar, Michael (1978), "Selection of an Effectve Channel Control Mix." Journal of Marketing, 42 (July), 53-58.

Etgar, Michael and Zusman Pinhas (1982), " The Marketing Intermediary as an Information Seller: A New Approach.” Journal of Business, 55 (October), 505-516.

Florence, P. Sargeant (1933), The Logic of Industrial Organisation. London: Routledge and Kegan Paul.

Ford, David I. ed. (1990), Understanding Business Markets: Interaction, Relationships and Networks. London: Dryden Press.

Ford, David I. ed. (1997), Understanding Business Markets: Interaction, Relationships and Networks. 2nd Edition, London: Dryden Press.

Ford, David I. (1980), "The Development of Buyer-Seller Relationships in Industrial Markets." European Journal of Marketing, 15 (5/6), 339-354.

Ford, David I, Gadde, Lars-Erik, Hakansson, Hakan, Lundgren, Anders, Snehota, Ivan, Turnbull, Peter, Wilson, David (1998), Managing Business Relationships. Chichester:UK, Wiley.

Forrester, Jay W. (1961), Industrial Dynamics Cambridge. Mass: MIT Press.

Frazier Gary L. and Antia Kersi D. (1995), "Exchange Relationships and Interfirm Power in Channels of Distribution." Journal of the Academy of Marketing Science, 23 (Fall), 321327.

Frazier Gary L. and Lassar, Walfried M. "Determinants of Disribution Intensity.” Journal of Marketing 60 (October), 39-51.

Frazier, Gary L. and Rody, Raymond C. (1991), "The Use of Influence Strategies in Interfirm Relationships in Industrial Product Channels.” Journal of Marketing, 55:1 (January), 5269.

Frazier, Gary L. and Sommers, John O. (1986), "Perceptions of Power Use in Franchised Channels.” Journal of Marketing Research, 23 (May), 228-236.

Frazier, Gary L., James D. Gill and Sudhir H. Kale (1989), 'Dealer Dependence Levels and Reciprocal Actions in a Channel of Distribution in a Developing Country." Journal of Marketing, 53 (January), pp.50-69. 
Frazier, Gary L., Robert E. Spekman and Charles R. O'Neal (1988), "Just-in-Time Exchange Relationships in Industrial Markets", Journal of Marketing, 52 (October), 52-67.

Frazier, Gary L. \& John O. Summers (1984), 'Interfirm Influence Strategies and Their Application within Distribution channels.' Journal of Marketing, 48 (Summer), 43-55.

Galbraith, John K. (1956), American Capitalism: The Concept of Countervailing Power. Boston: Houghton Mifflin .

Gaski, John F. (1984), “The Theory of Power and Conflict in Channels of Distribution." Journal of Marketing, 48 (Summer), 9-29.

Gaski, John F. and John R. Nevin (1985), 'The Differential Effects of Exercised and Unexercised Power Sources in a Marketing Channels. 'Journal of Marketing Research, 22 (May), 130-142.

Gattorna, John (1978), "Channels of Distribution Conceptualisations: A State of the Art Review." European Journal of Marketing, 12 (7), 471-512. .

Gemunden, Hans Georg (1997), "The Development of IMP - an Analysis of Conference Proceedings 1984-1996.” in Gemunden, Hans Georg, Ritter, Thomas and Walter, Achim eds, Relationships and Networks in International Markets. Oxford England, Pergamon/ Elsevier Science, 3-12.

George K. D. (1962), Productivity in Distribution. Cambridge University Press.

Gerstner, E., Hess, J. D. (1995), Pull promotions and channel coordination. Marketing Science, $14(1), 43-60$.

Geyskens, Inge, Steenkamp, Jan-Benedict E.M., Kumar, Nirmalya (1998), “Generalizations about trust in marketing channel relationships using a meta-analysis." International Journal of Research in Marketing, 15 (3), 223-248.

Geyskens, Inge, Steenkamp, Jan-Benedict E.M., Kumar, Nirmalya (1999), “A Meta-analysis of Satisfaction in Marketing Channel Relationships.” Journal of Marketing Research, 63 (May), 223-238.

Ghosh Mrinal and John, George (1999), "Governance Value Analysis and Marketing Strategy." Journal of Marketing, 63 (Special Issue), 131-145.

Glaser, S. (1985), "The Marketing System and the Environment", European Journal of Marketing, 19 (4), 54-70.

Glaser, S. \& M.I. Halliday (1984), "A Theory and Verities of Market Place Behaviour", Journal of Economic Psychology, 5 (2,) 159-176. 
Guilhaus, F. W. (1978), "Exclusive Dealing, Contractual Control and Dealer Discretion.” Management Forum, 4 (3), 197-210.

Guilhaus F. W. (1980), "An Empirical Study of Industrial Power and Conflict: Australian Petroleum Retailing." Journal of Industrial Relations, 22 (December), 400-419.

Guilhaus F.W. (1981), “A Comparative Study of Industrial Power, Control and Conflict: Australian Petroleum, Automobile and Fast Food Retailing." Management Forum, 7 (3), 168-193.

Gunesan, Shankar (1994), "Determinants of Long-Term Orientation in Buyer-Seller Relationships." Journal of Marketing, 58 (April), 1-19.

Haines, George H. Jr., Simon, Leonard S. and Alexis, Marcus (1971), "The Dynamics of Commercial Structure in Central City Areas.” Journal of Marketing, 35 (April), 10-18.

Hakansson, Hakan (1982), International Marketing and Purchasing of Industrial Goods, An Interaction Approach. John Wiley, Chichester.

Hakansson, Hakan (1989), Corporate Technological Behaviour, Co-operation and Networks. Routledge, New York.

Hakansson Hakan and David I Ford (forthcoming 2002), "How Should Companies Interact?" Journal of Business Research.

Hakansson, Johanson, Jan and Wootz, B. (1975)'Influence Tactics in Buyer-Seller Processes." Industrial Marketing Management, 5 (1), 25-36.

Hakansson, Hakan and Snehota, Ivan (1995), Developing Relationships in Business Networks. London: Routledge. .

Hall, Margaret (1949), Distributive Trading. London: Hutchinson's University Library.

Hall, Margaret, Knapp J. and Winsten, C. B. (1962), Distribution in Great Britain and North America. Oxford, UK: Oxford University Press.

Hall, R. H. (1972), Organization, Structure, and Process. Englewood-Cliffs, N.J.: Prentice-Hall.

Hallen, Lars (1982), "International Purchasing in a Small Country: An Introductory Study of Five Swedish Firms.” Journal of International Business Studies, 12 (Winter), 99-112.

Hallen, Lars, Johanson, Jan, Seyed Mohamed, N. (1991), "Interfirm Adaptation in Business Relationships." Journal of Marketing, 55 (April), 29-37.

Hallen, Lars and Wiedersheim-Paul (1979), "Psychic Distance and Buyer-Seller Interaction." Organization Marknad och Samhalle, 16 (5), 308-324. 
Heide, Jan and John, George (1992), "Do Norms Matter in Marketing Relationships?." Journal of Marketing, 56 (April), 32-44.

Heide, Jan and John, George (1990), "Alliances in Industrial Purchasing: The Determinants of Joint Action in Buyer -Seller Relationships." Journal of Marketing Research, 27 (February), 24-36.

Hollander, Stanley C. (1960)“The Wheel of Retailing.” Journal of Marketing, 24 (July), 37-42.

Hollander, Stanley (1966), "Notes on the Retail Accordion.” Journal of Retailing, 42 (2), 2940,54 .

Hunger, David J. and Stern, Louis W. (1976), "An Assessment of the functionality of Superordinate Goals in Reducing Conflict." Academy of Mangement Journal, 19 (December), 591-605.

Hunt, Shelby (1972), “The Socio-economic Consequences of Franchise Distribution.” Journal of Marketing, 36 (July), 32-38 .

Iacobucci, Dawn (1992), "Modeling Dyadic Interactions and Networks in Marketing,," Journal of Marketing, 29 (February), 5-17.

Iacobucci Dawn ed. (1996), Networks in Marketing. Thousand Oaks, CA: Sage Publications.

Iacobucci, Dawn and Hibbard, Jonathan D. (1998), “Toward an encompassing theory of business marketing relationships (BMRS), and interpersonal commercial relationships (ICRS): An empirical generalization." Journal of Interactive Marketing, 13 (3), 13-33.

Ingene, Charles (1985), "Labour Productivity in Retailing: What do we know and how do we know it." Journal of Marketing, 49 (4), 99-106.

Jeuland, A., Shugan, S. M. (1988), "Channel of distribution profits when channel members form conjectures." Marketing Science, 7 (Spring) 202-210.

Johanson Jan and Mattsson, Lars-Gunnar (1988), "Internationalisation in Industrial Systems - A Network Approach." in N. Hood and J. E. Valhne eds. Strategies in Global Competition. New York: Croom Helm, 287-314.

Johanson, J., and Lars-Gunnar Mattsson (1987), "Interorganisational Relations in Industrial Systems: A Network Approach compared with a Transaction Cost Approach." International Studies in Management and Organisation, 18 (1), 34-48.

Johanson, J., and Lars-Gunnar Mattsson (1994), "The Markets-as-Networks Tradition in Sweden,." in G. Laurent, G. Lillen and B. Prass eds. Research Traditions in Marketing. Boston, Kluwer, 321-342.

John, George (1984), “An Empirical Investigation of Some Antecedents of Opportunism in a Marketing Channel.” Journal of Marketing Research, 48 (August), 278-289. 
John, George and Reve, Torger (1982), "The Reliability and Validity of of Key Inormant Data from Dyadic Relationships in Marketing Channels.” Journal of Marketing Research, 19 (11), 517-524.

Johnson, J.L., Sakano, T., Cote, J.A., \& Onzo, N. (1993), “The Exercise of Interfirm Power and Its Repercussions in U.S.-Japanese Channel Relationships.” Journal of Marketing, 57 (April), 1-10. .

Johnston, Wesley J. and Thomas V. Bonoma (1981), "The Buying Center: Structure and Interaction Patterns." Journal of Marketing, 45 (Summer), 143-156.

Journal of Marketing Channels (1994), Special Issue: Japanese Distribution Channels, 3 (3).

Kale, Sudhir H. (1986), "Dealer perceptions of manufacturer Power and Influence Strategies in a Developing Country." Journal of Marketing Research, (November), 387-393.

Kalwani, M.U. and N. Narayandas (1995), "Long Term Manufactuer-Supplier Relationships: Do They Pay Off for Supplier Firms?.” Journal of Marketing, 59 1 1-16.

Keep, William W., Hollander Stanley C. and Dickinson, Roger (1998), .” Forces Impinging on Long-Term Business-to-Business Relations in the United States: An Historical Perspective." Journal of Marketing, 62 (April), 31-45.

Kinch, N. (1987), "Emerging Strategies in a Network Context: The Volvo Case.” Scandinavian Journal of Management, 3 (May), 167-184. .

Kinch, N. (1993), "The Long-Term Development of a Supplier-Buyer Relationship: TheCase of Olofström and Volvo." Paper presented at the 9th IMP Conference, University of Bath.

Kim, Sang Yong and Staelin, Richard (1999), "Manufacturer Allowances and Retailer PassThrough Rates in a Competitive Environment.” Marketing Science 18 (1), 59-76.

Kreisberg, Louis (1955), “Occupational Controls Among Steel Distributors.” American Journal of Sociology, 61 (November), 203-212. .

Lambkin, Mary and Day, George S. (1989), "Evolutionary Processes in Competitive Markets: Beyond the Product life Cycle." Journal of Marketing, 53 (July), 4-20.

Langton, Christopher G. ed. (1996), Artificial Life: An Overview. Boston: MIT Press. .

Layton, Roger (1981a), “Trade Flows in Macromarketing Systems: Part I.” Journal of Macromarketing 1(Spring),35-48.

Layton, Roger (1981b), “Trade Flows in Macromarketing Systems: Part II: Transforming Input/Ouput Tables into Trade Flow Tables.” Journal of Macromarketing, 1 (Fall), 4855 . 
Layton, Roger (1984), "Trade Flows in Australia, 1974-5: An Assessment of Structural Change." Journal of Macromarketing, 4 (Spring), 62-73.

Layton, Roger (1985), "Marketing Systems in Regional Economic Development." Journal of Macromarketing, 5 (Spring), 42-55.

Lee, E., Staelin, Richard (1997), "Toward the general theory of channel man-agement strategy." Marketing Science, 16 (3), 185-207. .

Lewis, Edwin H. (1968), Marketing Channels: Structure and Strategy. New York: McGrawHill.

Liljegren, Goren (1988), Interdependence and dynamics in Company Long-term Customer Relationships: Industrial Selling, a Network Perspective. Doctoral Thesis, Stockholm School of Economics, Market Technology Centre.

Little, Robert W. (1970), "The Marketing Channel: Who Should Lead this Extra Corporate Organization.” Journal of Marketing, 34:1 (January), 31-38.

Lundgren, Anders (1995), Technological Innovation and Network Evolution. London:

Routledge.

Lusch, Robert F. (1976a), "Channel Conflict: Its Impact on Retailer Operating Performance." Journal of Retailing, 52 (Summer), 3-12.

Lusch, Robert F.(1976b), "Sources of Power: Their Impact on Intrachannel Conflict.” Journal of Marketing Research, 13 (November), 382-390.

Lusch, Robert F. (1977), "Franchisee Satisfaction: Causes and Consequences.” International Journal of Physical Distribution Management, 7 (February), 128-140.

Macauley S. (1963), Non-Contractual Relations in Business: A Preliminary Study, American Sociological Review, 28 (February), 55-67.

MacInness, W. (1964), “A Conceptual Approach to Marketing..” In R. Cox, W. Alderson and S. Shapiro eds. Theory in Marketing: 2nd Series. Homewood, Ill: Richard D. Irwin. ?????

MacNeil, Ian R. (1980), The New Social Contract, An Enquiry into Modern Contractual Relations. Yale University Press, New Haven, CT.

Mallen, Bruce (1963), "A Theory of Retailer-Supplier Conflict, Control and Cooperation." Journal of Retailing, 39 (Summer), 24-32 and 51.

Mallen, Bruce ed. (1967), The Marketing Channel. New York: Wiley.

Mallen, Bruce (1973), "Functional Spinoff: A Key to Anticipating Change in Distribution Strucure." Journal of Marketing, 37 (July), 18-25. 
Mallen, Bruce (1977), Principles of Marketing Channel Management. Lexington, MA, Lexington Books.

March, James G. (1996), "Continuity and Change in Theories of Organizational Action." Administrative Science Quarterly, 41 (June), 278-287.

March James G. and Simon Herbert (1959), Organizations. New York: Wiley.

Marshall, Alfred (1898), Principles of Economics. New York: MacMillan.

Marshall, Alfred (1919), Industry and Trade. New York: MacMillan.

McCammon Jr., Bert C.(1963), "Alternative Explanations of Institutional Change and Channel Evolution.” In Stephen A. Greyser ed. Toward Scientific Marketing. Chicago: American Marketing Association, 477-90.

McCammon Jr., Bert C. and Little R.W. (1965), "Marketing Channels: Analytical Systems and Approaches.” In George Schwartz, ed. Science in Marketing. New York: Wiley, 75-81.

McGarry, Edmund G. (1951), "The Contactual Function in Marketing." Journal of Business, 24 (April), 96-113.

McGuire, T. W., R. Staelin. (1983), “An industry equilibrium analysis of downstream vertical integration.” Marketing Science, 2 (Spring), 161-192. .

McIntyre David R. (1977), "Your Overseas Distribution Action Plan - A Key to Strategic Marketing Planning." Journal of Marketing, 41 (April), 88-90.

McNair, Malcom and May Eleanor (1976), The Evolution of Retail Institutions in the United States. Cambridge Mass: Marketing Science Institute.

McVey, Phillip (1960), “Are Channels of Distribution What the Textbooks Say?” Journal of Marketing, 24 (January), 61-65.

Messinger, P. R., C. Narasimhan. (1995), "Has power shifted in the grocery channel?" Marketing Science, 14 (2), 189-223. .

Michman Ronald D., Gable, Myron and Sims, Taylor (1976), Marketing Channel Strategy: A Selected and Annotated Bibliography. Chicago: American Marketing Association.

Mohr, Jakki, Fisher, Robert J. and Nevin, John R. (1996), " Collaborative Communication in Interfirm Relationships: Moderating Effects of Integration and Control." Journal of Marketing, 60 (July), 103-115.

Moorman, Christine, Deshpande, Rohit and Zaltman, Gerald (1992), "Factors Affecting Trust in Market Research Relationships.” Journal of Marketing, 57 (January), 81-101. 
Morgan, Robert M. and Shelby D. Hunt (1994), "The Commitment-Trust Theory of Relationship Marketing." Journal of Marketing, 58 (July), 20-38 .

Mavondo, Felix T. and Elaine M. Rodrigo (2001), "The effect of relationship dimensions on interpersonal and interorganizational commitment in organizations conducting business between Australia and China." Journal of Business Research, 52 (2), 111-121.

Moyer, Reed and Hollander, Stanley C. (1968), Markets and Marketing in Developing Economies. Illinois: Irwin.

Nelson, Richard R. and Sidney G. Winter (1982), An Evolutionary Theory of Economic Change. Cambridge, MA: Belknap Press of Harvard University Press. .

Noordewier, Thomas G., John, George, and Nevin John R. (1990), "Performance Outcomes of Purchasing Arrangements in Industrial Buyer-Vendor Relationships." Journal of Marketing, 54 (October), 80-93.

Olsen, Janeen E. and Granzin Kent L. (1990), "Economic Development and Channel Structure: A Multinational Study." Journal of Macromarketing, 10 (Fall) 61-77.

Olsen, R.F. and Ellram L.M. (1997), “A Portfolio Approach to Supplier Relationships.” Industrial Marketing Management, 26, 101-113.

Ortiz-Buonofina, Marta (1987), "The Economic Efficiency of Channels of Distribution in Developing Society: The Case of the Guatemalan Retail Sector." Journal of Macromarketing, 7 (Fall) 17-25.

Palamountain, Joseph C. (1955), The Politics of Distribution Cambridge: Harvard University Press.

Pearson, Michael and John F. Monoky (1976), "The Role of Conflict and Cooperation in Channel Performance." in K Berhardt ed. Marketing 1776-1976 and Beyond. American Marketing Association Educators Proceedings, 39, 240-247.

Penrose, Edith (1959), The Theory of the Growth in the Firm. Oxford Blackwell.

Phillips, Lynn W. (1981), “Assessing Measurement Error in Key Informant Reports: A Methodological Note on Organisational Analysis in Marketing." Journal of Marketing Research, 18 (November), 395-415.

Porter, Michael E.(1974), "Competitive Behavior, Retailer Power and Marketing Performance in Consumer Goods Industries." Review of Economics and Statistics, 56 (November), 419-436.

Purohit, Devavrat and Staelin, Richard (1994), "Rentals, Sales, and Buybacks: Managing Secondary Distribution Channels." Journal of Marketing Research, 31 (August), 325338. 
Reilly, William J. (1931), The Law of Retail Gravitation. University of Texas.

Revzan, David A. (1961), Wholesaling in Marketing Organization. New York: John Wiley.

Richardson G. B. (1972), “The Organisation of Industry.” Economic Journal, 80 (September), 883-896.

Ridgeway, Valentine (1957), “Administration of Manufacturer Dealer Systems.” Administrative Science Quarterly, 1 (March), 464-467.

Rindfleisch, Aric and Heide, Jan B. (1997), "Transaction Costs Analysis: Past, Present and Future Appolications.” Journal of Marketing, 61 (October), 30-54.

Ritter, Thomas (1999), "The Networking Company: Antecedents for Coping with Relationships and Networks Effectively.” Industrial Marketing Management, 28 (5), 467-479.

Robicheaux, Robert A. \& Adel I. El- Ansary (1976), “A General Model for Understanding Channel Member Behaviour.” Journal of Retailing, 52 (Winter), 13-30, 93-94.

Robinson E.A.G. (1931), The Structure of Competitive Industry. New York: New York University Press.

Rosenberg, Larry J. \& Louis W. Stern, (1970), "Toward the Analysis of Conflict in Distribution Channels: A Descriptive Model." Journal of Marketing, 34 (October), 40-46.

Rosson, Philip J. \& I. David Ford (1982), "Manufacturer - Overseas Distributor Relations and Export Performance.” Journal of International Business Studies, 12 (Fall), 57-72.

Roy, Beau (1998), "Using Agents to Make and Manage Markets Across a Supply Web." Complexity 3 (4), 41-5.

Ruerkert Robert W. and Churchill Gilbert A. (1984), "Reliability and Validity of Alternative Measures of Channel Member Satisfaction.” Journal of Marketing Research, 21 (May), 226-233.

Schul, Patrick L. Pride, William W. and Little, Taylor E. (1983), “The Impact of Channel Leadership Behavior on Intra-Channel Conflict.” Journal of Marketing, 47 (3), 35-44.

Schumpeter, Joseph (1939), Business Cycles. New York: McGraw-Hill.

Schumpeter, Joseph (1947), Capitalism, Socialism and Democracy. New York: Harper's.

Sharma, Neeru and Patterson, Paul (2000), "Switching Costs, alternative attractiveness and experience as moderators of relationship commitment in professional, consumer services." International Journal of Service Industry Management, 11 (5), 470-490.

Shove, G. F. (1930), "The Representative Firm and Increased Returns." Economic Journal, 40 (March) 94-116. 
Shugan, S. 1985. Implicit understandings in channels of distribution. Management Science, 31 (April), 435-460.

Slater, Charles C. (1968), "Marketing Processes in Developing Latin American Societies." Journal of Marketing, 32 (July), 50-55.

Steiner, Robert L. (1978), "Marketing Productivity in Consumer Goods Industries - A Vertical Perspective." Journal of Marketing, 42 (January), 60-70.

Stern, Louis W. (1967), “The Concept of Channel Control.” Journal of Retailing, 53 (Summer), 14-20.

Stern, Louis W. (1969), Distribution Channels: Behavioral Dimensions. Boston:Mass., Houghton Mifflin Coy.

Stern, Louis W. and El-Ansary, Adel I. (1982), Marketing Channels. 1st Edition, Prentice-Hall.

Stern, Louis W. \& Torger Reve (1980), "Distribution Channels as Political Economies: A

Framework for Comparative Analysis." Journal of Marketing, 44 (Summer), 52-64.

Stern, Louis W., Brian Sternthal \& C. Samuel Craig (1973), "A Parasimulation of

Interorganisation Conflict.” International Journal of Group Tensions, 3 (1/2) 68-90.

Stewart, P.W., Dewhurst J. F. and Field F. (1939), Does Distribution Cost Too Much? New York: The Twentieth Century Fund.

Stigler, George J. (1946), The Theory of Price. New York: MacMillan.

Stigler, George J. (1951), "The Division of Labour is Limited by the Extent of the Market." Journal of Political Economy, 95 (June), 185-193.

Sturdivant, Frederick D. and Granbois D. L. (1968), "Channel Interaction: An Insitutional Behavior View." The Quarterly Review of Economics and Business, 8 (Summer), 61-8.

Thompson, J. (1967), Organizations in Action. New York: McGraw-Hill.

Thorelli, H.B. (1986), "Networks: between markets and hierarchies." Strategic Management Journal, 7 37-51.

Turnbull Peter and Cunningham Malcom T. (1981), International marketing and Purchasing. London: MacMillan.

Turnbull, Peter, David I. Ford, and Malcom Cunningham (1996), "Interaction, Relationships and Networks in Business Markets: an evolving perspective." Journal of Business and Industrial Marketing, 11 (3/4), 44-62. .

Turnbull, Peter and Valla, Jean-Paul eds. (1986), Strategies for International Industrial Marketing. London: Croom Helm. 
Vaile, Roland, Grether, E. T. and Cox, Reavis (1952), Marketing in The American Economy. New York: The Ronald Press.

Van de Ven, Andrew (1993), "The Institutional Theory of John R. Commons: A Review and Commentary." Academy of Management Review, 18 (January), 139-152.

Wadinambiaratchi, George (1965), "Channels of Distribution in Developing Economies." The Business Quarterly, 30 (Winter), 74-82.

Walters, Glenn C. (1974), Marketing Channels. New York, Ronald Press.

Ward T.S. (1973), Distribution of Consumer Goods: Structure and Performance. Cambridge University Press.

Webster Frederick E. Jr. (1992), “The Changing Role of Marketing in the Corporation.” Journal of Marketing, 56 (October), 1-17.

Welch, Denice, Welch, Lawrence, Wilkinson Ian F. and Young, Louise C. (1996), "Network Development in International Project Marketing and the Impact of External Facilitation." International Business Review, 5 (6), 579-602.

Welch, Denice, Welch, Lawrence, Wilkinson Ian F. and Young, Louise C. (1998), "The Importance of Networks in Export Promotion: Policy Issues." Journal of International Marketing, 6 (4), 66-82.

Wilkinson Ian F. (1976), "An Exploration of Methodologies for Detecting Subgroups, Subsystems and cliques of firms in Distribution Channels." Journal of the Academy of Marketing Science, (Winter), 539-553.

Wilkinson, Ian F. (1979), "Power and Satisfaction in Channel of Distribution." Journal of Retailing, 55 (2) 79-94.

Wilkinson, Ian F. (1990), "Toward a Theory of Structural Change and Evolution in Marketing Channels." Journal of Macromarketing, 10 (Fall) 18-46 .

Wilkinson Ian F. and Easton, Geoff (1997), "Edge of Chaos II: Industrial Network Interpretation of Boolean Functions in NK Models.” In F. Mazet, R. Salle and J-P Valla eds., Interaction Relationships and Networks in Business Markets: Volume II. Lyon: Groupe ESC, .

Wilkinson, Ian F. Lars-Gunnar Mattsson and Geoff Easton (2000), "International Competitiveness and Trade Promotion Policy from a Network Perspective." Journal of World Business, 35 (Fall), 275-299.

Wilkinson, Ian F. Wiley, James and Easton, Geoff (1999), "Simulating Industrial Relationships with Evolutionary Models." Proceedings $28^{\text {th }}$ European Marketing Academy Annual Conference. Humboldt University, Berlin, May $12-14^{\text {th. }}$ 
Wilkinson, Ian F. Wiley, James B and Lin, Aizhong (2001), "Modelling the Structural Dynamics of Industrial Networks." Interjournal: Complex Systems, article \# 409, http://interjournal.org/.

Wilkinson, Ian F and Young Louise C. (1989), "1989 Survey of Interfirm Relations - Preliminary Findings,.” Report 89/3 Interfirm Relations Research Program, School of Marketing. Sydney, University of New South Wales.

Wilkinson, Ian F and Young Louise C. (1996), "Business Dancing - The Nature and Role of Interfirm Relations in Business Strategy." Asia-Australia Marketing Journal, 2 (1), 6779.

Wilkinson, Ian F and Young Louise C. (forthcoming), "On Cooperating: Firms, Relations and Networks." Journal of Business Research.

Williamson, Oliver E. (1975), Markets and Hierarchies: Analysis and Anti-Trust Implications. The Free Press, New York.

Williamson, Oliver E. (1981), "The Modern Corporation: Origins, Evolution, Attributes.” Journal of Economic Literature, 16 (December), 1537-1568.

Wilson, David T. and Moller, Kristian (1988), "Buyer Seller Relationships: Alternative Conceptualizations." Report 10-1988, Institute for the Study of Business Markets. University Park, PA: Pennsylvania State University.

Wilson, David T. and Jantrania, Swati (1996), "Understanding the Value of a Relationship.” AsiaAustralia Marketing Journal, 2 (1), 55-66.

Wittreich, Warren J. (1962), “Misunderstanding the Retailer.” Harvard Business Review, MayJune, 147-159.

Woodward, Joan (1965), Industrial Organization: Behaviour and Control. New York: Oxford University Press.

Young, Louise C. \& Ian F. Wilkinson (1989), "The role of Trust and Cooperation in Marketing Channel: A Preliminary Study.” European Journal of Marketing, 23 (2) 109-22.

Young, Louise C. and Ian F. Wilkinson (1997), "The Space Between: Towards a Typology of Interfirm Relations." Journal of Business to Business Marketing, 4 (2), 53-97.

Zusman, Pinhas and Etgar Michael (1981), The Marketing Channel as an Equilibrium Set of Constracts." Management Science, 27 (March), 284-302. 
Table 1 Founding Economic Principles

Contributor:

Marshall 1898,1919

Shove 1930

Robinson, 1931

Florence 1933

Stigler 1946, 1951

Hall 1949

Boulding 1953

Penrose 1959

\section{Contribution}

Scale efficiencies, marketing and distance

Expansion and distance

Economies of specialization

Types of scale, principles of multiples, bulk transactions, massed reserves

Pooled uncertainty, division of labor and market size

Principle of minimized total transactions

Non proportional change

Differential growth of the firm 
Table 2 Early Marketing Network Theorists 1920s to 1950s

Name: $\quad$ Contribution

Macklin 1921

Breyer 1924, 1949

Reilly 1931

Twentieth Century Fund 1939

McGarry 1951

Vaile, Grether and Cox 1952

Duddy and Revzan 1953

Aspinwall 1956

Cox and Goodman 1956
Efficient Marketing

Channel and channel group costing

Retail Gravitation

Distribution Cost

Contactual function

Collecting, Sorting and Dispersing, flows

Holistic-institutional approach

Color of goods and Distribution systems

Philadelphia housebuilding study 


\section{Table 3 Aldersonian Network Principles}

\section{Function Concepts:}

Transactions and transvections

Sorts and Transformations

Discrepancy of Assortments

Sorting: Allocation, Accumulation, Sorting out, Assorting

Routine and fully negotiated transactions

Postponement Vs speculation

\section{Structure Concepts}

Organized behavior systems

Operation and Power Structure

Cooperation and competition

Monostasy and systasy

Dynamics \& the proliferation of opportunity

Power Principle 
Table 4 The Development of Research on interfirm relations in Channel and Business Networks in the Journal of Marketing and Journal of Marketing Research 19701999

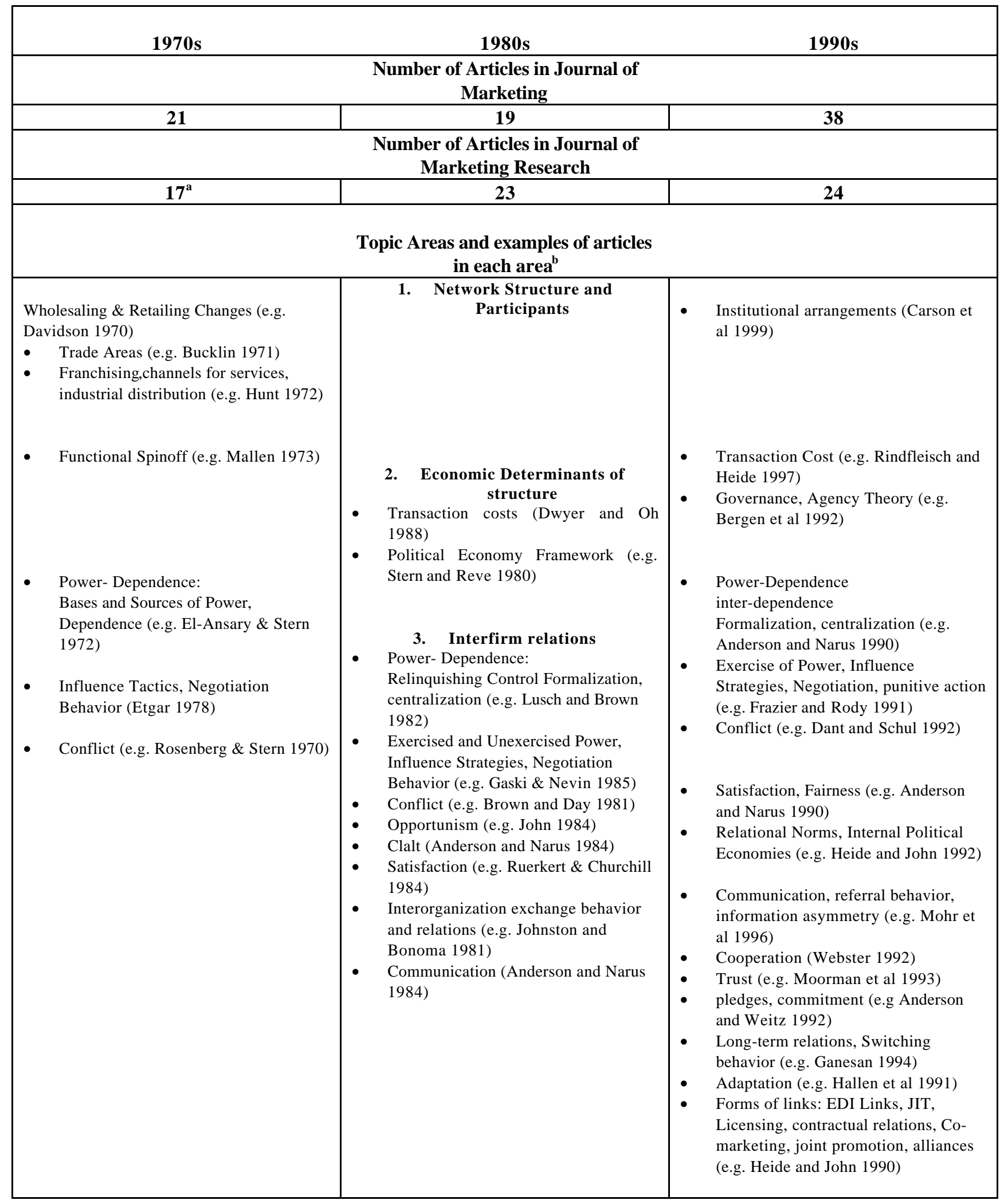


- Distribution Dynamics (e.g. Haines et al 1971)

- $\quad$ Simulation/modelling (e.g. Bowersox et al 1972)

- Channel Control, Authority Leadership (e.g. Little 1970)

- $\quad$ Channel Management \& Planning (e.g. Moyer \& Whitmore 1976)

- Performance, efficiency, productivity (e.g. Steiner 1977)

- $\quad$ socio-economic consequences (e.g. Hunt 1972)
4. Network Dynamics, Change and Evolution

- Distribution Dynamics (e.g. Lambkin and Day 1989)

- Relationship development (e.g. Dwyer Schurr and Oh 1987,

\section{Network Strategy, Design and} Management

- Resource Allocation, portfolio analysis (e.g. Dickson 1983)

6. Network Performance and Impacts

- Performance Efficiency (Stern and Reve 1980)

7. Network Environment

- Environment Uncertainty, Munificence (e.g Achrol et al 1983)

- International contexts (Frazier et al 1989)

8. Methodology

- Key informants (Phillips 1981)

- Reliability and Validity (e.g. Ruekert and Churchill 1984)
- Channel evolution (e.g. Achrol 1991)

- Network positioning (e.g. Anderson et al 1994)

- Complexity (Achrol 1991)

- Design and Management (e.g. Purohit and Staelin 1994)

- Intensity (e.g. Frazier and Lasser 1996)

- $\quad$ Performance, Efficiency (e.g. Noordeweier et al 1990)

- $\quad$ Value (e.g. Ghosh and John 1999)

- Environment Turbulence (e.g. Achrol 1991)

- $\quad$ Networks (e.g. Anderson et al 1994)

- International contexts (e.g. Johnson et al 1993)

- $\quad$ Network Analysis (e.g Iacobucci and Hopkins 1992)

Notes:

a. The Journal of Marketing Research Articles 1970s include Research Notes and Communications, including four comments and reply articles relating to empirical studies of channel relations

$\mathrm{b}$ The example article cited is generally the first published during the period. Some articles are cited more than once because they cover more than one topic area. 


\section{Footnotes}

\footnotetext{
* Previous versions of this paper have been presented at seminars and at the IMP Conference in 2000. I should like to acknowledge the contributions of those that have read and commented on earlier versions of this paper and discussed with me the way particular research streams developed. In particular I should mention Don Dixon, Robert Dahlstrom, Hakan Hakansson, Jan Johansson and Louise Young as well as the constructive comments of two anonymous reviewers. Of course, all the remaining errors and omissions are mine.

${ }^{1}$ I do not include a discussion of theory of imperfect competition developed by Edwin Chamberlin and Joan Robinson even though this is in many ways the foundation for modern marketing theory. This is because the theory does not directly deal with business network structure and operations

${ }^{2}$ For a review of Commons' contributions to management theory see Van De Ven (1993)

${ }^{3}$ For a fuller discussion see Dixon and Wilkinson (1986).

${ }^{4}$ I am indebted to Don Dixon for calling my attention to the importance of Macklin's contribution.

5 Another important group of researchers was developing among academics teaching marketing in the far western states of the USA. (e.g. Duncan 1958) including researchers such as Balderston, Grether and Revzan.
}

${ }^{6}$ As indicated, for example, in Alderson 1957 and Alderson and Cox (1948)

${ }^{7}$ These ideas were in part developed with McGuiness (1964).

${ }^{8}$ Bucklin (1970) was another book of original articles exploring the behavioral dimension of channels.

${ }^{9}$ This included Porter's (1974) study of retailer power based on economic statistics

${ }^{10}$ Wilson and Moller (1988) identified 44 constructs used in the study of business relationships

${ }^{11}$ This research was based on that conducted by Lusch $(1976 \mathrm{a}, 1976 \mathrm{~b})$ in the USA and involved nationwide studies of the petroleum and automobile retailing. Unfortunately they never got published in journals easily accessible to a wider audience.

${ }^{12}$ The journal has since been renamed the Australasian Marketing Journal and become the official journal of the Australia New Zealand Marketing Academy.

${ }^{13}$ The review by Webster of business marketing was interesting in that it did not mention any of the IMP studies. This reflected the continuing divide between American and European researchers, despite greater interaction and collaboration.

14 One area that is already gaining much research attention is the nature and role of electronic commerce and its impact on relations between firms and with final customers. This new context for interaction will 
undoubtedly shape the nature and development of relations but it should be possible to identify key contextual dimensions that underlie its impact, rather than to propose new explanatory variables. For example the speed, extent and character of interaction is not the same as face to face communication or telephone or other written forms and these affect who can communicate with whom and the way relations develop. 